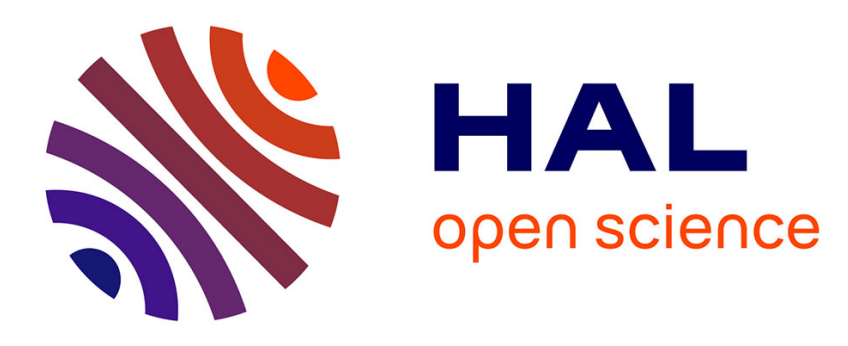

\title{
Holocene Land Cover and Population Dynamics in Southern France
}

\author{
Jean-françois Berger, Stephen Shennan, Jessie Woodbridge, Alessiano \\ Palmisano, Florence Mazier, Laure Nuninger, Sebastien Guillon, Elise Doyen, \\ Carole Bégeot, Valérie Andrieu-Ponel, et al.
}

\section{To cite this version:}

Jean-françois Berger, Stephen Shennan, Jessie Woodbridge, Alessiano Palmisano, Florence Mazier, et al. Holocene Land Cover and Population Dynamics in Southern France. The Holocene, 2019, 29 (5), pp.776-798. 10.1177/0959683619826698 . hal-01860670

\section{HAL Id: hal-01860670 https://hal.science/hal-01860670}

Submitted on 10 Apr 2019

HAL is a multi-disciplinary open access archive for the deposit and dissemination of scientific research documents, whether they are published or not. The documents may come from teaching and research institutions in France or abroad, or from public or private research centers.
L'archive ouverte pluridisciplinaire HAL, est destinée au dépôt et à la diffusion de documents scientifiques de niveau recherche, publiés ou non, émanant des établissements d'enseignement et de recherche français ou étrangers, des laboratoires publics ou privés. 


\title{
Holocene land cover and population dynamics in Southern France
}

\author{
Jean-François Berger,' Stephen Shennan, ${ }^{2}$ Jessie Woodbridge, ${ }^{3}$ \\ Alessio Palmisano, ${ }^{2}$ (i) Florence Mazier, ${ }^{4}$ Laure Nuninger, ${ }^{5}$ \\ Sebastien Guillon, ${ }^{6}$ Elise Doyen, ${ }^{5}$ Carole Begeot, ${ }^{5}$ \\ Valérie Andrieu-Ponel, ${ }^{7}$ Julien Azuara, ${ }^{8}$ id Andrew Bevan, ${ }^{2}$ \\ Ralph Fyfe ${ }^{3}$ and C Neil Roberts ${ }^{3}$
}

\begin{abstract}
This paper describes long-term changes in human population and vegetation cover in southern France, using summed radiocarbon probability distributions and site count data as population proxies and information from fossil pollen cores as a proxy for past land cover. Southern France is particularly wellsuited to this type of study as a result of previous programmes of intensive survey work and excavation in advance of large-scale construction. These make it possible to calibrate the larger scale occupation patterns in the light of the visibility issues created by the burial of archaeological sites beneath alluvial sediments. For purposes of analysis, the region was divided into three biogeographical zones (BGZ), going from the Mediterranean coast to the middle Rhône valley (MRV). All the different population proxies in a given zone show broadly similar patterns of fluctuation, though with varying levels of resolution. The long-term patterns in the different zones all show significant differences from the overall regional pattern, but this is especially the case for the non-Mediterranean middle Rhône area. Cluster analysis of pollen samples has been carried out to identify the main regional land cover types through the Holocene, which are increasingly dominated by open types over time. A variety of other pollen indicators show evidence of increasing human impact through time. Measures of human impact correlate strongly with the population proxies. A series of thresholds are identified in the population-human impact trajectory that are related to other changes in the cultural sequence. The lack of independent climate data for the region means that its impact cannot currently be assessed with confidence. However, for the later periods, it is clear that the incorporation of southern France into larger regional systems played a major role in accounting for changes in land cover and settlement.
\end{abstract}

\section{Keywords}

aoristic weights, Holocene, human impact, land cover, pollen, population dynamics, population proxy, radiocarbon summed probability distribution, site count, Southern France

Received 25 July 2018; revised manuscript accepted 4 January 2019

\section{Introduction}

In the Mediterranean region, separating the impact of human activity from climate remains a challenging task (Roberts et al., 2011), but all the more important because over recent millennia Mediterranean environments have become very vulnerable to the emergence of new risks (Leveau, 2007; Van der Leeuw et al., 2005). Identifying the rhythms, intensity and scales of the processes involved is essential for understanding the causes of change in any socio-environmental system and their impacts. In order to do so, it is necessary to adopt a broad scale of spatial and temporal analysis focusing on key factors including demography, subsistence techniques, vegetation and soil erosion. This paper addresses long-term trends in population and land cover in southern France, one of the main settlement areas in the western Mediterranean.

In this region, the impacts of the first Neolithisation in the early to mid 8th millennium BP (see Table 1 for cultural chronology) are still largely considered local and negligible (Richard, 2004). A first threshold is envisaged in the Middle Neolithic, a millennium later, with the establishment of settlement networks extending from the plains to the mountains (Beeching,
1991), the first pastoral systems associated with the widespread use of cave-sheepfolds (Brochier et al., 1999) and the development of true oak parklands (Delhon et al., 2009). From the late Neolithic (5000-4500 cal. yr BP), the spread of sclerophyllous taxa and loss of forest cover could result mainly from

\footnotetext{
'Université de Lyon, CNRS, Université Lyon 2-Lumière, France 2Institute of Archaeology, University College London (UCL), UK ${ }^{3}$ School of Geography, Earth and Environmental Sciences, University of Plymouth, UK

${ }^{4}$ UMR Laboratoire GÉODE, Université Toulouse II - Jean Jaurès, France 5Laboratoire Chrono-Environnement, University of Franche-Comté,

France

6Independent Researcher, France

${ }^{7}$ Institut Méditerranéen de Biodiversité et d'Écologie Marine et Continentale (IMBE), France

8 Muséum National d'Histoire Naturelle, France
}

\section{Corresponding author:}

Stephen Shennan, University College London (UCL), 3 I-34 Gordon Square, London WCIH OPY, UK.

Email: s.shennan@ucl.ac.uk 
Table I. Cultural chronology of southern France in the Holocene.

\begin{tabular}{|c|c|}
\hline Period & Absolute dates \\
\hline Sauveterian Mesolithic & $9700-6700 / 6600 \mathrm{BCE} \mid \mathrm{II}, 650-8650 / 8550 \mathrm{BP}$ \\
\hline Castelnovian Mesolithic & $6700 / 6600-5600 / 5500 \mathrm{BCE} \mid 8650 / 8550-7550 / 7450 \mathrm{BP}$ \\
\hline Early Neolithic-Impressa & 5900/5800-5600 ВCE|7850/7750-7550 ВP \\
\hline Early Neolithic-Cardial/Epicardial & 5600/5500-4800 BCE|7550/7450-6750 BP \\
\hline Early to Middle Neolithic transition & $4800-4600 \mathrm{BCE} \mid 6750-6550 \mathrm{BP}$ \\
\hline Middle Neolithic - Prechassean (Fagien/St Uze) & $4600-4400 \mathrm{BCE} \mid 6550-6350 \mathrm{BP}$ \\
\hline Middle Neolithic - Early Chassean & 4400-4000 BCE|6350-5950 BP \\
\hline Middle Neolithic - Late/Tardi Chassean & $4000-3600 / 3400 \mathrm{BCE} \mid 5590-3550 / 3350 \mathrm{BP}$ \\
\hline Late Neolithic I - St Ponien/Ferrières/Couronnien/NerasienI & 3500/3400-3100/2900 BCE|5450/5350-5050/4850 BP \\
\hline Late Neolithic II -Verazien II/Fontbouisse/Rhône-Ouvèze & $3000 / 2900-2500 / 2400$ BCE|4950/4850-4450/4350 BP \\
\hline Late Neolithic III - Rhodano-Provencal Bell Beaker & $2500-2200 / 2$ I50 BCE|4450-4I50/4100 BP \\
\hline Early Bronze Age I/ceramics with barbed decor & $2150-1900 \mathrm{BCE} \mid 4100-3850 \mathrm{BP}$ \\
\hline Early Bronze Age II & |900-|700 BCE|3850-3650 BP \\
\hline Early Bronze Age III & $|700-1600 / / 550 \mathrm{BCE}| 3650-3550 / 3500 \mathrm{BP}$ \\
\hline Middle Bronze Age I & |600//550-1450 BCE|3550/3500-3400 BP \\
\hline Middle Bronze Age II-III & |450-1350 BCE|3400-3300 BP \\
\hline Late Bronze Age I & $|350-| 200 \mathrm{BCE}|3300-3| 50 \mathrm{BP}$ \\
\hline Late Bronze Age lla & $|200-| 150 \mathrm{BCE}|3| 50-3100 \mathrm{BP}$ \\
\hline Late Bronze Age Ilb & II50-1050//025 BCE|3100-3000/2975 BP \\
\hline Late Bronze Age Illa & 1050/1025-900 BCE|3000/2975-2850 BP \\
\hline Late Bronze Age Illb & $900-800 / 750$ BCE|2850-2750/2700 BP \\
\hline Iron Age I & 750-500 BCE|2700-2450 BP \\
\hline Iron Age II-Early la Tène & $500-300 \mathrm{BCE} \mid 2450-2250 \mathrm{BP}$ \\
\hline Iron Age II-Middle la Tène & 300-200 BCE|2250-2150 BP \\
\hline Iron Age II-Late La Tène & 200-12। BCE|2150-207| BP \\
\hline Roman-High Empire & 12। BCE-300 CE|207|-1650 BP \\
\hline Roman-Low Empire & $300 \mathrm{CE}-458 / 493 \mathrm{CE} \mid 1650-1492 / 1457 \mathrm{BP}$ \\
\hline Early Middle Age & 493-900 CE| |457-1050 BP \\
\hline Central Middle Age & $900-1300 \mathrm{CE} \mid 1050-650 \mathrm{BP}$ \\
\hline Upper Middle Age & |300-|492 CE|650-458 BP \\
\hline
\end{tabular}

Cultural transitions are presented with variations corresponding to inter-regional differences: after Beeching (200I), Denaire et al. (20II), Guilaine and Manen (2005), Gutherz and Jallot (1999), Lachenal (2012), Lemercier (2004) and Vital (2012).

anthropogenic impacts on vegetation (Pons and Quézel, 1998; Vernet and Thiébault, 1987), although a climatic explanation of the same phenomena has also been offered (Jalut et al., 2000, 2009). The end of the Iron Age and the Roman (Gallia Narbonensis) and Medieval periods see major human modification of environments and landscapes.

Central to analysing the causal links and processes behind these developments is the reconstruction of human population dynamics at different scales - Mediterranean France as a whole and its different biogeographic sub-regions - in order to compare the results with independent data on land cover. A long-established approach to modelling population dynamics in a diachronic perspective is to use the counts of archaeological sites dated to established typo-chronological phases, but for much if not most of Holocene prehistory these phases are not short enough to provide a useful degree of chronological resolution and the methods implicitly assume that changes occur only at phase boundaries. In recent years, as the number of radiocarbon dates available has increased, it has been shown that summed radiocarbon date probabilities (SPD) provide a useful additional proxy for fluctuations in human population levels, at a much higher level of resolution for most of prehistory and without having to be concerned with the impact of artificial typo-chronological phase boundaries (Shennan et al., 2013; Timpson et al., 2014). However, it has also been demonstrated that at some point in the 1st millennium BCE, depending on the region, this proxy loses its usefulness as researchers switch to increasing use of typo-chronological dating (which is now much more fine-grained than earlier, for example, Palmisano et al., 2017).
Southern France provides an exceptionally good case-study region for documenting long-term population trends. Large numbers of radiocarbon dates are available and regional reports provide a strong set of site count data (see Supplemental Material 1, available online, for a full list of sources) for quantitative comparison. Moreover, these regional data can also be compared with the results of previous micro-regional studies that have made southern France one of the best-documented regions of the Mediterranean for quantitative archaeological analysis (Archeomedes and Archaedyn surveys, Favory et al., 1999; Gandini et al., 2012; Van der Leeuw et al., 2003). It is also one in which taphonomic processes have been extensively documented by numerous rescue archaeology operations over 30 years in the Middle Rhône Valley (MRV; for example, the Mediterranean TGV express train line, pipelines and urban expansion projects), which can be used to estimate the number of sites invisible on the surface (Berger, 2011, 2015; Verhagen and Berger, 2001), though there are no large diachronic quantitative syntheses at the scale of southern France that go back beyond the last three millennia (see below).

Southern France also possesses a large number of pollen records for reconstructing past land-cover. Although several reviews have tried to decipher the causes of long-term Mediterranean vegetation change, there is still no clear understanding of the respective role of past human activities and climate in vegetation change (Azuara et al., 2015, 2018; de Beaulieu et al., 2005; Jalut et al., 2000, 2009). This is partly due (a) to the chronology (age-depth models), which is still a limiting factor when comparing several pollen records, (b) to the definition of similarities and differences in vegetation patterns when exploring multiple pollen 


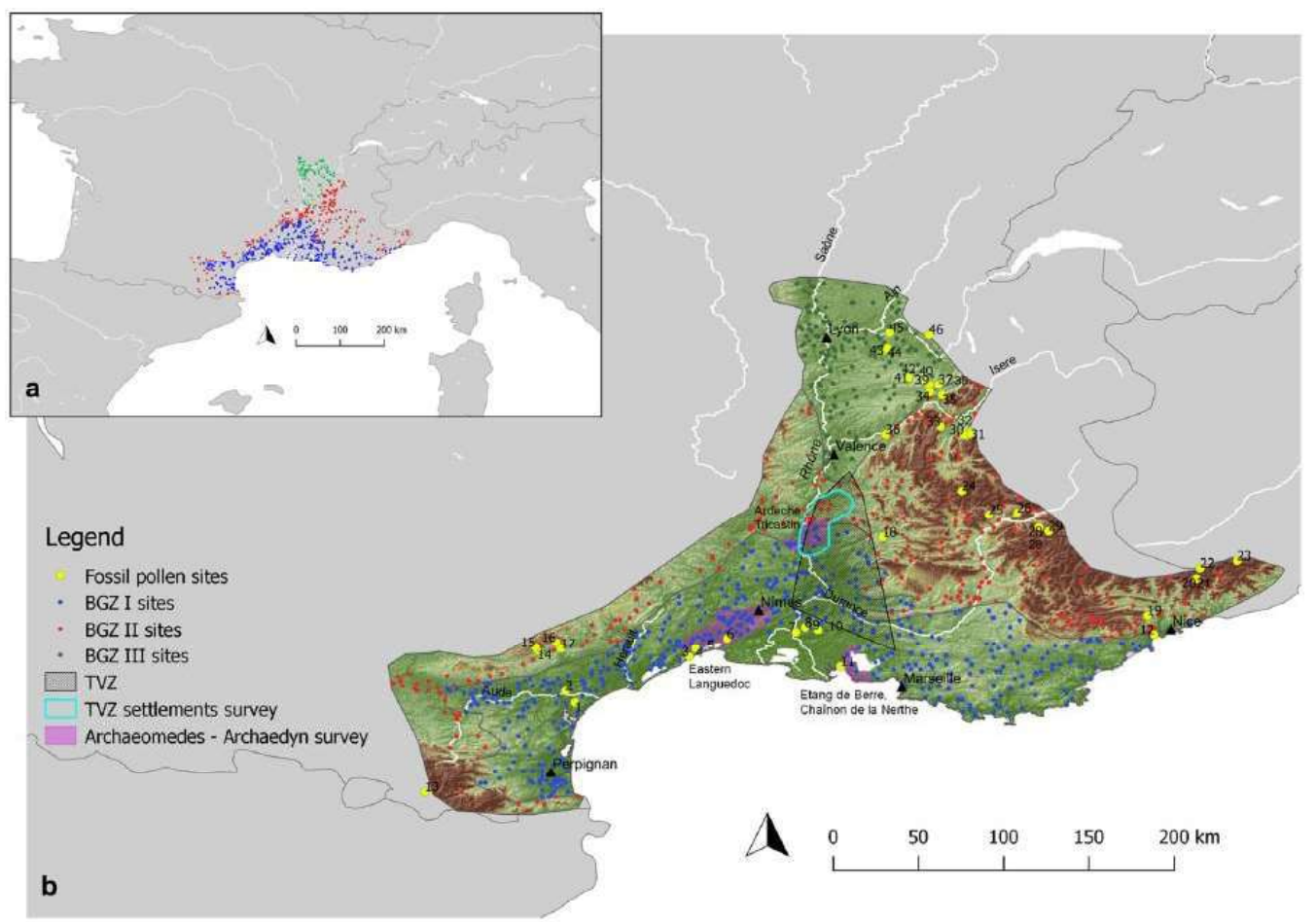

Figure I. Map of the southern France study area showing the location of the pollen samples (numbers correspond to those in Table 2) and the archaeological sites. The boundaries of the Tricastin-Valdain settlement survey area (TVZ), the broader TVZ area that includes radiocarbon dates from recent rescue excavations and the three Archaeomedes II - ArchaeDyn survey areas are also shown: Eastern Languedoc: Archaeomedes II - ArchaeDyn, 1996-2012, archaeological data: C. Raynaud, F. Favory, L. Nuninger, M.-J. Ouriachi, E. Fovet;Ardèche \& Tricastin: Archaeomedes II 1996-1998, archaeological data:J. Goury, C. Jung; Etang de Berre \& Chaînon de la Nerthe:Archaeomedes II 1996-1998, archaeological data: F.Trément, F. Gâteau.

records and (c) to the difficulties of relating them to independent climatic and population proxies. Recently, pollen sequences and their chronologies from the European Pollen Database (EPD) have been reviewed and corrected (Fyfe et al., 2009) in order to compare those sequences. New use of cluster analysis has also offered useful results for exploring past vegetation change (Fyfe et al., 2018; Woodbridge et al., 2018).

The aim of this paper is to remedy the lack of synthetic quantitative land-cover and population studies, and to test how far regional vegetation changes and ecological transformations within southern France can be explained by archaeologically derived records of demographic change $(10,000-500 \mathrm{BP})$, while evaluating the validity of the regional archaeological data through comparison with the results of the previous micro-regional studies. Regional trends in vegetation through the Holocene are derived from synthesis of multiple pollen sequences.

\section{The study area}

The area of southern France examined here, the 'French Mediterranean South', covers nearly $100,000 \mathrm{~km}^{2}$ and is located at the north-western edge of the Mediterranean morpho- and bioclimatic system (latitude $42.5^{\circ}$ to $46^{\circ}$ N., Figure 1), just south of a zone characterised by mid-European and Alpine climatic influences. As a basis for our spatial and chronological analysis of the archaeological and pollen records, we have divided it into three homogeneous biogeographical zones (BGZ), which correspond to a topographic, climatic and latitudinal gradient along the Rhône corridor and its tributaries as far as its confluence with the River Saône in Lyon, and in the western part along the main river basins that run from the southern Massif Central and eastern Pyrenees. They are the coastal and hinterland eu/meso-mediterranean lowlands (BGZ I), the supra-Mediterranean uplands (BGZ II) and the MRV and low Dauphiné (BGZ III) (Figure 1)).
BGZ I covers the southern coastal band from Nice to Perpignan and its hinterland up to $500 / 600 \mathrm{~m}$ in altitude (almost $40,000 \mathrm{~km}^{2}$ ). The regional climate is characterised by a strong summer drought close to the coast and in lowland Provence, which weakens as you move northwards up the Rhône Valley or into the mountainous foothills (BGZ II and III). Seasonal rainfall maxima are in the autumn, with a rainy season from September to April and little summer rainfall. The intensity of the rains and the irregularity of precipitation from 1 year to the next result in rivers with strongly contrasted regimes. High river flows occur during September and October and again in spring in the river Rhône, as the snow melts in the Alps.

BGZ II corresponds to the supra-Mediterranean to mountainMediterranean zones, which follow a continuous calcareous prealpine zone (c. $47,000 \mathrm{~km}^{2}$ ) associated with karstic relief in the eastern part of the study area, from 500 to $2000 \mathrm{~m}$ in altitude. These areas have many caves and rock shelters conducive to pre- and proto-historic settlement. They are also favourable to the concentration of fortified sites on the edges of plateaus or on barred spurs. In the western part of the region (Languedoc), the BGZ II band is much narrower because the transition from the high plateaux of the southern part of the Massif Central takes place very abruptly. Further south this band is associated with the foothills of the eastern Pyrenees. This zone is defined quite well to the north by the area where olive cultivation becomes impossible because of the cold, and often by the disappearance of the summer rainfall lull.

BGZ III corresponds to the middle basin of the Rhône ( $c$. $13,000 \mathrm{~km}^{2}$ ), between its exit from the southern Jura and the northern Alps where the Guiers and Ain rivers converge, and its confluence with the basins of the Western calcareous pre-Alps (Vercors, Diois), where the Rhône is joined by the Isère and the Drôme rivers (Figure 1). In this zone of climatic convergence (Mediterranean, oceanic and alpine), the alluvial plains, quaternary terraces and moraines and many lakes and marshes resulting from glacial morphogenesis, predominate in the vast molassic sedimentary 
triangle of the low Dauphiné, forming an extensive detrital tertiary fan. This zone presents landscapes of hills, plateaus and active or dead alluvial valleys, the altitude of which does not exceed $600 \mathrm{~m}$.

From a hydrographic point of view, these three BGZs are crossed by the river Rhône, the backbone of the study area. This axis has had a strong structural effect on settlement and interaction throughout history, encouraging penetrations of people from the Mediterranean coast and north-south cultural exchanges with Central Europe.

\section{Methodology and materials}

\section{Archaeological data and demographic indicators}

The southern France region dataset. Archaeological datasets from southern France (sites and radiocarbon dates) have been collected as exhaustively as possible, either from extant online databases or manually input from print and electronic publications, in order to create two georeferenced databases, one for radiocarbon dates and one for archaeological sites (see Supplemental Material 1, available online, for a full list of sources). These are taken as the basis for demographic proxies that characterise major relative population trends at a regional scale.

A total of 3507 uncalibrated radiocarbon dates from 1056 sites have been collected for southern France. All of these radiocarbon dates are from archaeological contexts, with the majority being samples of bone, charcoal and wood. Radiocarbon dates exhibiting poorly understood reservoir effects such as marine samples from shells have been removed (and are not part of the above total).

A potential bias from the oversampling of specific sites or site-phases for radiocarbon was reduced by aggregating uncalibrated radiocarbon dates from the same site that are within 100 years of each other and dividing by the number of dates that fall in this 'bin' (Timpson et al., 2014). As a result our, 3507 radiocarbon dates have been grouped into 2490 bins. The probabilities from each calibrated date are combined to produce a summed probability distribution (SPD). Unnormalised dates were used prior to summation and calibrated via IntCal13 curve in order to avoid narrow artificial peaks in SPDs due to the effect of steepening portions of the radiocarbon calibration curve when normalised calibrated dates are used (Reimer et al., 2013; see previous applications in Bevan et al., 2017; Palmisano et al., 2017). A logistic null model, corresponding to the assumption that population would have gradually increased until a carrying capacity was reached, was fitted to the observed SPD in order to produce a $95 \%$ critical envelope (composed of 1000 random SPDs) and statistically tested to establish whether the observed pattern significantly departs from this model (see Bevan et al., 2017; Timpson et al., 2014: 555-556; and for the specific implementation Crema and Bevan, 2018: 'modelTest'). Radiocarbon SPDs were also created for each of the three biogeographic zones described above and permutation tests (Crema et al., 2016; Roberts et al., 2018) carried out to establish whether they were significantly different from the overall regional pattern. These data were also used to create a cave/rock shelter use index, representing the proportion of site-phases at a given time made up of these site types. This provides a basis for discussing the intensity of use of karstic environments.

Archaeological site data have been collected via a comprehensive review, standardisation and synthesis of settlement data from 45 reports (based on the Bilan Scientifique Regional) of archaeological investigations (excavations and surveys) carried out in the regions of Languedoc-Roussillon, Provence-AlpesCôte d'Azur and Rhône-Alpes. In this project, we collected data from the reports published between 2001 and 2015 (see Supplemental Material 1, available online, for a full list of references). The fiches de synthèse of the Archéologie du TGV Méditerranée have been added (Collectif, 2002a, 2002b, 2002c) for the Tricastin and Valdain areas (see below). Although this approach does not provide a complete census of all archaeological settlements in southeastern France, at this scale it provides a reliable subsample of the entire population both in terms of chronological and spatial coverage. Settlement data were recorded as geo-referenced points per cultural period, which have been defined in terms of calendar dates, though the chronological information given in the Bilans is often fairly imprecise. By recording both the stated cultural period and approximate estimated start and end dates in calendar years, we have sought nevertheless to provide maximum comparative potential across archaeological sites. One major caveat is that the estimated site surface area per cultural period was not consistently available, and therefore not recorded for all the sites stored in the two databases used here. As a consequence, in this paper, we use raw site counts (RC), and derivatives of these, as a proxy for population. A total of 2944 archaeological sites were divided into 4974 occupation phases (most sites were occupied in multiple periods). The main sociocultural entities of southern France discussed in this paper are given in Table 1, incorporating ranges of uncertainty between archaeological cultures or from one subregion to another.

Site counts have been calculated for each of a series of 200year time slices, starting at $10,000 \mathrm{cal}$. yr BP. Since cultural periods vary in their length according to the dating precision of archaeological artefacts, and the earlier ones tend to be longer, we have used aoristic analysis to deal with the temporal uncertainty of occupation periods and generated aoristic weights (AW; for a more detailed explanation of the methodology see Crema, 2012: 446-448; Crema et al., 2010: 1118-1121; Palmisano et al., 2017: 63-65). In addition, to mitigate the discrepancy between wide typo-chronological ranges and shorter likely site durations, we applied Monte Carlo methods to generate randomised start dates (RSD) of occupation phases for sites with low-resolution information, assuming a mean occupation length of 200 years within any given cultural period (cf. Crema, 2012: 450-451; Palmisano et al., 2017: 63-64). The resulting probabilistic distributions of site frequencies through time, based on the aoristic sums and Monte Carlo simulations, help to refine the raw site frequency data.

Micro-regional studies. In addition to the radiocarbon and sitecount data collected for the region as a whole, this paper also makes use of further micro-regional datasets collected by earlier projects within the region. These data provide a basis for calibrating and evaluating the broader regional patterns.

The 'Tricastin-Valdain' micro-regional zone (TVZ) at the interface between BGZ I and II (Figure 1: TVZ settlement survey zone) is probably the best archaeologically documented area from the Neolithic to Medieval period in Southern France. Over the past 30 years, a number of archaeological surveys have been carried out here, based on field walking projects that began in the 1980 s and increased in the 1990s under the combined action of CNRS (ATP 'First farmers', GDR 954), Ministry of Culture (H 11 Tricastin), and European ('Archaeomedes', Van der Leeuw, 2001) projects. In addition, a programme of mechanical trenching was carried out as part of the Mediterranean TGV (the high-speed railway) rescue archaeological project along a $120-\mathrm{km}$ strip on the left bank of the Rhône (INRAP, Gutherz and Odiot, 2001), as well as a $50-\mathrm{km}$ strip in the Valdain basin in advance of a pipeline (Berger, 2015; Figure 1: TVZ zone). This dataset provides a basis for evaluating the taphonomic impact of hydrogeomorphological processes on the initial relative population estimates based on the radiocarbon and site data described above because it is derived from a dataset randomly created during the excavation of linear mechanical trenches across the superficial deposits of the different landscape units. 
For later periods ( $800 \mathrm{BCE}-1600 \mathrm{CE})$, it is also possible to compare results from the overall dataset with those obtained by the Archaeomedes (1992-1996) and Archaedyn (2005-2011) projects, which provide a micro-regional database based primarily on systematic field-walking survey from three areas, that again began in the 1980s-1990s (PCR 'Land Use in Narbonnaise during Roman times' and GDR 954, see Favory et al., 2012): eastern Languedoc, Ardèche-Tricastin and Etang de Berre \& Chaînon de Ia Nerthe (see Figure 1: Archaeomedes Archaedyn survey areas). Only settlement remains were taken into account but, in addition to settlement-count, settlement-area information, based on the surface distribution of sherds and building material, was also available from these surveys, which therefore offer important additional information that other datasets do not. Furthermore, advanced analysis and classification of the settlements based on various criteria, allow discussion in more detail of population inferences for the last millennium BCE (Archaeomedes, 1998; Nuninger et al., 2012; Van der Leeuw et al., 2003) and the factors affecting them, such as the increasing impact of Mediterranean trade. Typo-chronological information provides a 100 year chronological resolution. These datasets, from areas between 100 and $1200 \mathrm{~km}^{2}$ contain 27 to 1061 settlement entities with 133 to 3121 occupations for these later periods.

\section{Pollen}

Modern and fossil pollen datasets. Within a Mediterranean-wide synthesis, pollen count data from the European modern (Davis et al., 2013) and fossil pollen databases (EPD version: Oct. 2017; Leydet, 2007-2017) were combined with additional fossil records provided by a network of data contributors (e.g. Andrieu-Ponel et al., 2000a, 2000b) to compile a dataset spanning the whole Mediterranean. Descriptions of the methodological approaches developed and applied to these pollen datasets are provided in Woodbridge et al. (2018) and Fyfe et al. (2018) along with detailed information on the pollen taxonomic harmonisation applied to allow comparisons between records. Pollen sequences with reliable chronologies (Giesecke et al., 2013) were selected for analysis and new sediment core chronologies were constructed for additional records using the 'bacon' $\mathrm{R}$ package (Blaauw and Christen, 2011). The pollen count data from each record were summed into 200-year time windows and analyses were applied to the entire Mediterranean region (1798 modern and 252 fossil records amounting to 6554 fossil sample time windows and modern surface samples) in order to identify key vegetation types. Analyses for a sub-set of 48 fossil records and 87 modern pollen sites are presented in this paper for southern France (see Table 2), which is split into the three biogeographic zones described above (coastal Mediterranean: 13 fossil and 13 modern sites, supraMediterranean: 20 fossil and 68 modern sites and middle Rhône: 12 fossil and 6 modern sites).

Data analysis. An unsupervised data-driven approach was applied to the entire Mediterranean pollen dataset to assign pollen samples, amalgamated into 200 year time windows, to vegetation cluster groups based on the similarity of their taxa assemblages, using Ward's hierarchical agglomerative clustering method (Ward, 1963) within the 'rioja' R package (Juggins, 2015) (see Woodbridge et al. (2018) and Fyfe et al. (2018) for a detailed description of the cluster analysis approach developed). A phytosociological classification approach (Perez et al., 2015) was used to identify the frequent and abundant pollen taxa within each cluster group based on their median and interquartile range (IQR). Interpretive name descriptors were given to each vegetation cluster using phytosociological classification tables together with comparisons with other classification systems, land cover types defined by Corine remotely sensed land cover maps and the results of previous studies (see Woodbridge et al., 2018). Pollen indicator groups were also used to summarise key changes in the datasets. This included calculating the average arboreal pollen sum (\%AP); a sum of tree crop indicators Olea, Juglans, Castanea (OJC) (Mercuri et al., 2013a) (also combined with Vitis, (OJCV)); calculation of an anthropogenic pollen index (API: Artemisia, Centaurea, Cichorioideae and Plantago, cereals, Urtica and Trifolium type) (Mercuri et al., 2013b); a sum of pastoral indicators (Asteroideae, Cichorioideae, Cirsium-type, Galium-type, Ranunculaceae and Potentilla-type pollen) (adapted from Mazier et al., 2006); and a sum of Regional Human Activity Pollen Indicators, RHAPI (Secale, Cerealia undiff., Chenopodiaceae, Artemisia, Urtica dioica, Plantago lanceolata, Plantago media/major, Rumex spp., Rumex obtusifolius type and Rumex actesosa/acetosella) (Mazier et al., 2006, 2009). Vegetation cluster group changes were calculated as an average for all sites in the southern France case study region and each sub-region and plotted stratigraphically.

For the specific purpose of comparison with the pollen, the demographic proxies (SPD of radiocarbon dates, raw count, aoristic sum and randomised start date) were further binned into 200year time slices to match the time windows used in the analysis of pollen sequences. A Spearman's Rank correlation matrix was calculated between the values of the human impact pollen indicators and the values of the archaeological demographic proxies in each time slice for the period 10,000 to $600 \mathrm{cal}$. yr BP. The rank correlations between the SPD of radiocarbon dates, and all other proxies have been calculated for a shorter time span, between 10,000 and 2400 cal. yr BP, because after this time the radiocarbon dates lose their value as a demographic proxy, as discussed above.

\section{Results}

\section{Demographic trends from archaeological data}

The 'Tricastin-Valdain' test dataset (TVZ). As described above, this intensively investigated area crossing BGZ I and II provides a basis for assessing the broader regional results. Figure $2 \mathrm{a}$ shows the different archaeological indicators on the same temporal axis (SPD, buried sites and caves-rock shelters, raw count as site density per 50 years up to the Iron Age II phase). The SPD data have been excluded from this analysis after $2400 \mathrm{cal}$. yr BP, when the $\mathrm{RC}$ data become the more reliable indicator of human population variation. A first increase is detectable around $8700 \mathrm{cal}$. yr BP. A second sharper increase is identified $c .7450 \mathrm{cal}$. yr BP, with two distinct maxima towards $7000-6700$ and 6350-6200 cal. yr BP. This period corresponds to the early and middle Neolithic (EMNT). A well-marked decrease is clearly identified in the SPD curves of surface and buried sites centred on 6600-6500 cal. yr BP and a second, less sharp, around 6000-5900 cal. yr BP. A third increase is detectable jointly by the SPD and the RC analysis from 5900 cal. yr BP with a double maximum around 5750 and $5500 / 5400$. A decrease in the number of sites characterises the end of this period. A fourth increase towards $5050 \mathrm{cal}$. yr BP is seen clearly in the SPD curves of both surface and buried sites, indicating a shift into the floodplains. The fifth increase is particularly marked, and common to all settlement markers from 4500 cal. yr BP. The set of curves then fluctuates regularly up to 3300 cal. yr BP, with maxima (4100-3950 and 3700-3600 cal. yr BP) and minima centred on 3800 then $3500-3400$ cal. yr BP, the latter a major decline marked by all indicators. The seventh increase corresponds to the entire Late Bronze Age (LBA, 3300-2700 cal. $\mathrm{yr} \mathrm{BP}$ ) and shows a strong correlation between all archaeological markers. The very large number of buried sites in the floodplain suggests that surface sites under-represent the number of sites for this period. Furthermore, the density of sites per 50 year period in this phase is at least twice as high as in the late Neolithic, a pattern 
Table 2. Southern France: fossil pollen sites.

\begin{tabular}{|c|c|c|c|c|c|c|c|c|}
\hline Code & Site name & Latitude & Longitude & Sub-region & Elevation & Contributor & Site information & Citation \\
\hline BAUXTCI & Marais de BauxI & 43.69778 & 4.780278 & I & 0 & Andrieu-Ponel & $\begin{array}{l}\text { Endoreic } \\
\text { depression }\end{array}$ & $\begin{array}{l}\text { Andrieu-Ponel et al. } \\
(2000 \mathrm{~b})\end{array}$ \\
\hline BAUXTC2 & Marais de Baux2 & 43.69778 & 4.780278 & 1 & 0 & Andrieu-Ponel & $\begin{array}{l}\text { Endoreic } \\
\text { depression }\end{array}$ & $\begin{array}{l}\text { Andrieu-Ponel et al. } \\
(2000 \mathrm{~b})\end{array}$ \\
\hline CAGNES & Cagnes & 43.3934 & 7.091 & I & 0 & Guillon & Coast & Guillon (2014) \\
\hline CALADEI & La Calade & 43.71583 & 4.686944 & 1 & 4 & Andrieu-Ponel & Marsh & $\begin{array}{l}\text { Andrieu-Ponel et al. } \\
(2000 \mathrm{a})\end{array}$ \\
\hline DESPORT & Desport & 43.636901 & 4.137408 & 1 & 2 & Guillon-Berger & $\begin{array}{l}\text { Delta of } \\
\text { Vidourle river, an } \\
\text { agricultural area }\end{array}$ & $\begin{array}{l}\text { Blanchemanche et al. } \\
\text { (2006) }\end{array}$ \\
\hline EMBOU & Embouchac & 43.566389 & 3.916667 & 1 & I & EPD & $\begin{array}{l}\text { Lagoon and delta } \\
\text { of Lez river }\end{array}$ & Puertas (1999) \\
\hline ETANG & $\begin{array}{l}\text { Le Grand Etang de } \\
\text { Suze-La-Rousse }\end{array}$ & 44.35 & 5.233333 & 1 & 92 & EPD & Field with corn & Argant (1990) \\
\hline FOSES4 & Marais de Fos & 43.436667 & 4.936667 & 1 & I & EPD & Peat bog & $\begin{array}{l}\text { Vella and Provansal } \\
(2000)\end{array}$ \\
\hline MONTADY & Etang de Montady & 43.1853 & 3.0654 & I & 20 & Guillon-Berger & $\begin{array}{l}\text { Endoreic } \\
\text { depression }\end{array}$ & Guillon (2007) \\
\hline OUVEIL2 & Etang d'Ouveillan & 43.266667 & 3 & I & 6 & EPD & $\begin{array}{l}\text { Agricultural and } \\
\text { cultivated area }\end{array}$ & Sanchez-Goñi (1995) \\
\hline PB06 & Palavas & 43.50778 & 3.870833 & 1 & -1 & Azuara & Lagoon & Azuara et al. (20I5) \\
\hline PITON & Piton & 43.68333333 & 4.62361111 & 1 & 5 & Baudouin & Alluvial delta & $\begin{array}{l}\text { Arnaud-Fasetta et al. } \\
(2005)\end{array}$ \\
\hline STSAU & Saint Sauveur & 43.566389 & 3.916667 & I & I & EPD & Lagoon & Puertas (1997) \\
\hline BAISSESC & Baïssescure & 43.55 & 2.8 & 2 & 1000 & EPD & Big bog & de Beaulieu (1974) \\
\hline BIOT & Biot & 43.8 & 7.1 & 2 & 863 & EPD & Valley & $\begin{array}{l}\text { Nicol-Pichard and } \\
\text { Dubard (1998) }\end{array}$ \\
\hline CORREO & Correo & 44.508333 & 5.983056 & 2 & 1090 & EPD & Peat gutter & Nakagawa (1998) \\
\hline GATIMORT & $\begin{array}{l}\text { Tourbière de } \\
\text { Gatimort }\end{array}$ & 43.575278 & 2.785556 & 2 & 970 & EPD & $\begin{array}{l}\text { Ombrotrophic } \\
\text { peat }\end{array}$ & Pulido (2006) \\
\hline LANDE & $\begin{array}{l}\text { Tourbière de la } \\
\text { Lande }\end{array}$ & 43.566667 & 2.966667 & 2 & 1040 & EPD & Peat & Pulido (2006) \\
\hline LAUI & Lac du Lauzon & 44.675278 & 5.793333 & 2 & 1980 & EPD & Lake & $\begin{array}{l}\text { Argant and Argant } \\
(2000)\end{array}$ \\
\hline LLONGI & Lac Long Inférieur & 44.057778 & 7.45 & 2 & 2114 & EPD & $\begin{array}{l}\text { Lake with marginal } \\
\text { fen }\end{array}$ & de Beaulieu (1977) \\
\hline LUITEL & Col Luitel & 45.088333 & 5.849722 & 2 & 1250 & EPD & $\begin{array}{l}\text { Lake of the pass of } \\
\text { Luitel }\end{array}$ & Wegmüller (1977) \\
\hline MONTSEC2 & $\begin{array}{l}\text { Tourbière de Mont } \\
\text { Sec }\end{array}$ & 45.068889 & 5.806667 & 2 & 1130 & EPD & Peat bog & Nakagawa (1998) \\
\hline MOUTON2 & Lac Mouton & 44.057778 & 7.444722 & 2 & 2175 & EPD & Lake & de Beaulieu (1977) \\
\hline PELL79C2 & Pelléautier & 44.522222 & 6.183333 & 2 & 975 & EPD & $\begin{array}{l}\text { Nowadays a lake } \\
\text { due to a dam }\end{array}$ & de Beaulieu (1977) \\
\hline PEUIL & Peuil Peat Bog & 45.125 & 5.643611 & 2 & 970 & EPD & Peat bog & Nakagawa (1998) \\
\hline PEYROUTA & $\begin{array}{l}\text { Tourbière de la } \\
\text { Peyroutarié }\end{array}$ & 43.609444 & 2.931389 & 2 & 1054 & EPD & Peat & Pulido (2006) \\
\hline PRAVER & Lac de Praver & 45.073611 & 5.856389 & 2 & 1170 & EPD & $\begin{array}{l}\text { Oligotrophic lake } \\
\text { with peat bog }\end{array}$ & Nakagawa (1998) \\
\hline RAC20 & Lake Racou & 42.554167 & 2.008333 & 2 & 2000 & EPD & Mire & Guiter et al. (2005) \\
\hline RATZ8I & Saint Julien de Ratz & 45.348333 & 5.655278 & 2 & 673 & EPD & Lake & Clerc (1988) \\
\hline SABBIONI & Sabbion & 44.13 & 7.473333 & 2 & 2216 & EPD & Peat & de Beaulieu JL (2010) \\
\hline SJSL972 & Lac Saint Léger & 44.42 & 6.336389 & 2 & 1308 & EPD & $\begin{array}{l}\text { Bog on the shore } \\
\text { of the lake }\end{array}$ & de Beaulieu (1977) \\
\hline SJSLS & Lac Saint Léger & 44.42 & 6.336389 & 2 & 1308 & EPD & $\begin{array}{l}\text { Bog on the shore } \\
\text { of the lake }\end{array}$ & $\begin{array}{l}\text { Digerfeldt et al. } \\
\text { (1997) }\end{array}$ \\
\hline VALPROV2 & Vallon de Provence & 44.391111 & 6.404167 & 2 & 2075 & EPD & $\begin{array}{l}\text { Low marsh with } \\
\text { Cyperaceae }\end{array}$ & de Beaulieu (1977) \\
\hline AMBY86 & Hières sur Amby & 45.790833 & 5.283333 & 3 & 227 & EPD & Agricultural area & Clerc (1988) \\
\hline CERINTB3 & Lac Cerin & 45.777222 & 5.561944 & 3 & 781 & EPD & $\begin{array}{l}\text { Peat bog with little } \\
\text { lake }\end{array}$ & Bossuet et al. (1996) \\
\hline CHIRENSI & $\begin{array}{l}\text { Tourbière de } \\
\text { Chirens }\end{array}$ & 45.423333 & 5.561667 & 3 & 460 & EPD & Bog & Eicher et al. (198I) \\
\hline CZEI & Marais de Charauze & 45.368333 & 5.566944 & 3 & 375 & EPD & Marsh & Argant (2010) \\
\hline HILAIRE2 & $\begin{array}{l}\text { Saint Hilaire du } \\
\text { Rosier }\end{array}$ & 45.070833 & 5.256667 & 3 & 190 & EPD & Marsh & $\begin{array}{l}\text { de Beaulieu et al. } \\
\text { (1982) }\end{array}$ \\
\hline LEMPS83 & Le Grand Lemps & 45.473333 & 5.416667 & 3 & 680 & EPD & Woods & Clerc (1988) \\
\hline
\end{tabular}


Table 2. (Continued)

\begin{tabular}{lllllllll}
\hline Code & Site name & Latitude & Longitude & Sub-region & Elevation & Contributor & Site information & Citation \\
\hline LEMPS86 & Le Grand Lemps & 45.473333 & 5.416667 & 3 & 680 & EPD & Woods & Clerc (1988) \\
LORAS84 & Loras & 45.666389 & 5.243333 & 3 & 416 & EPD & Lake & Clerc (2010) \\
MORAS & Moras & 45.68194444 & 5.26833333 & 3 & 304 & Doyen & Lake & Doyen et al. (2013) \\
PALADRU & Paladru & 45.45 & 5.53333333 & 3 & 492 & Begeot & Lake & Doyen et al. (2016) \\
SIXTE79 & Saint Sixte & 45.425833 & 5.628611 & 3 & 720 & EPD & Lake & Clerc (1988) \\
SIXTE85 & Saint Sixte & 45.425833 & 5.628611 & 3 & 720 & EPD & Lake & Clerc (1988) \\
\hline
\end{tabular}

EPD: European Pollen Database.

broadly matched by the buried site SPD, suggesting that the surface site SPD peak in this period is exaggerated compared with the LBA. The beginning of the Iron Age (2700-2600 cal. yr BP) corresponds to a short, very marked fall, which all the settlement markers record simultaneously. The end of the Iron I and the beginning of the Iron II period show a new increase in the density of human settlement, concentrated in the hills, plateaux and floodplains. The number of sites identified is then lower than during the LBA, but the size of the hilltop sites (oppida) increases significantly, which our data do not take into account. From the Iron Age II, the raw count data were the only variable used to describe the Tricastin-Valdain settlement dynamic. A maximum centred on the high Roman Empire (150 sites) is followed by a slow decline until the 5 th century CE ( 50 sites) and then a further abrupt decline until the 7th century CE (12 sites); a second maximum is centred on the High Middle Ages (12th-13th centuries CE; between 80 and 90 sites), with growth starting in the 10th century.

The representativeness of the radiocarbon pattern can be assessed by means of a permutation test to see if the SPDs for surface and buried sites in the TVZ deviate from the $95 \%$ critical interval generated by permuting subsets of all the TVZ dates (Figure $2 \mathrm{~b}$ and $\mathrm{c})$. The difference is not significant $(p=0.153)$ though it is clear that c. 3300-2700 cal. yr BP, the buried site line is at the very top of the $95 \%$ interval (and conversely for the surface sites) and would indeed be significantly different if a larger sample of buried site dates maintained the same pattern, because the $95 \%$ interval would be narrower. However, it seems that both surface and buried sites describe similar demographic trends throughout the Holocene.

The three biogeographic zones. Figure 3 shows a logistic model fitted to the SPD data from southern France as a whole. The pattern is significantly different from that described by this logistic model, with positive departures between 10,000 and 8500,5000 and 4000 and between 1500 and 1000 cal. yr BP, corresponding to periods when population was higher than expected, while there are shorter-lived negative departures indicating population declines, at c. 5500, 3500, 3000 and 2500 cal. yr BP. Despite the overall consistency of shape in each of the regional time series, permutation tests (Figure $4 \mathrm{a}-\mathrm{c}$ ) also demonstrate that all three regions differ significantly from the overall pattern, implying certain localised dynamics at least until the 1st millennium BCE. BGZ I is the closest, with a positive departure between 5000 and 4000 cal. yr BP. BGZ III, however, is almost completely different from the overall picture, being significantly lower until $4000 \mathrm{BP}$ and significantly higher from $3500 \mathrm{cal}$. yr BP. BGZ II shows a major negative departure in the later part of the period, but by this time, the radiocarbon data no longer give a valid picture of the trends. Figure 5 shows the radiocarbon and site-derived proxies (raw count, aoristic weight and randomised start date) together (the values of each proxy have been normalised on a scale between 0 and 1 in order to make them comparable) and it is apparent that from c. $2300 \mathrm{cal}$. yr BP the site-derived proxies show an order of magnitude increase on what has gone before, which is not matched in the SPD, reflecting the much greater use of typo-chronological dating and increasing settlement density in the late Iron Age and Roman period.

It is possible to obtain a general impression of the representativeness of the radiocarbon pattern for BGZ I and II by comparing it with the SPD for the Tricastin-Valdain area (the hatched area on the map, Figure 1), by means of a permutation test, as above, though it is important to note that the TVZ covers only a relatively small part of the two zones and thus cannot be regarded as truly representative of the area as a whole. Nevertheless, with this caveat in mind, it can be seen that the TVZ curve generally falls within the critical envelope for the combined zones (Figure 4d). Discounting the difference in the last part of the sequence when radiocarbon is no longer the preferred dating method, the only area of marked difference occurs around $3000 \mathrm{cal}$. yr BP, when it appears that LBA sites are under-represented, presumably because more of them occur in floodplains, as we saw in the TVZ, and are less likely to be recovered in normal archaeological investigations.

From the early Holocene at $\sim 10,000$ cal. $\mathrm{yr} B P$, there is a steady increase of population until $7400 \mathrm{cal}$. yr BP, which corresponds to the first real threshold in the site-count data (Figure 5). The SPD shows a first increase in density in the karstic area (caves/rock shelters) and in the open-air sites around 7400 in BGZ II and 7200 cal. yr BP in BGZ I, in correlation with the RC curve which really turns upwards at $7600 \mathrm{cal}$. yr BP. Comparison of the cave-rock shelter SPD with the $95 \%$ MC envelope for southeast France as a whole (Figure 4e) shows that karst habitat predominates over open-air occupation from 10,000 to $6300 \mathrm{cal}$. $\mathrm{yr} \mathrm{BP}$, though it is possible that this also reflects better preservation and discovery probabilities in caves over this period. A second threshold appears to be crossed at 6300 cal. yr BP (early Chassean) in the open air sites in the three zones, correlated in BGZ I with the karst habitat. During the late Chassean (59005600 cal. yr BP), use of the karst habitat is greatly reduced, while the open-air occupation of BGZ II and III increases significantly. At the beginning of the late Neolithic, the open-air settlement (SPD) remains stable in BGZ I between 5600 and 5350 cal. yr BP, before increasing strongly from $5300 \mathrm{BP}$, while in BGZ II and III it records a simultaneous decline in open air sites and caves/rock shelter (5600-5300 BP) at the mid-late Neolithic transition.

Throughout the second part of the LN and the early Bronze Age (EBA), the SPD curves of the BGZ I and II show the same trend in open air sites, with an increase in density marked by a first jump at $4850 \mathrm{cal}$. yr BP, followed by an absolute maximum of synchronous density between $4450-4250 \mathrm{cal}$. yr BP (Figure $5 \mathrm{a}$ and b). The high SPD in BGZ I from 5300 to $3900 \mathrm{cal}$. yr BP may be exaggerated by research bias. Nevertheless, the RC value is also very high in BGZ I and II in this period, which therefore represents a true demographic maximum compared with the EMNT Middle Neolithic (Figure 5). However, as noted above, the results from the TVZ suggest that it is exaggerated in comparison with the LBA (3300-2700 cal. yr BP). BGZ III, the Middle Rhone 

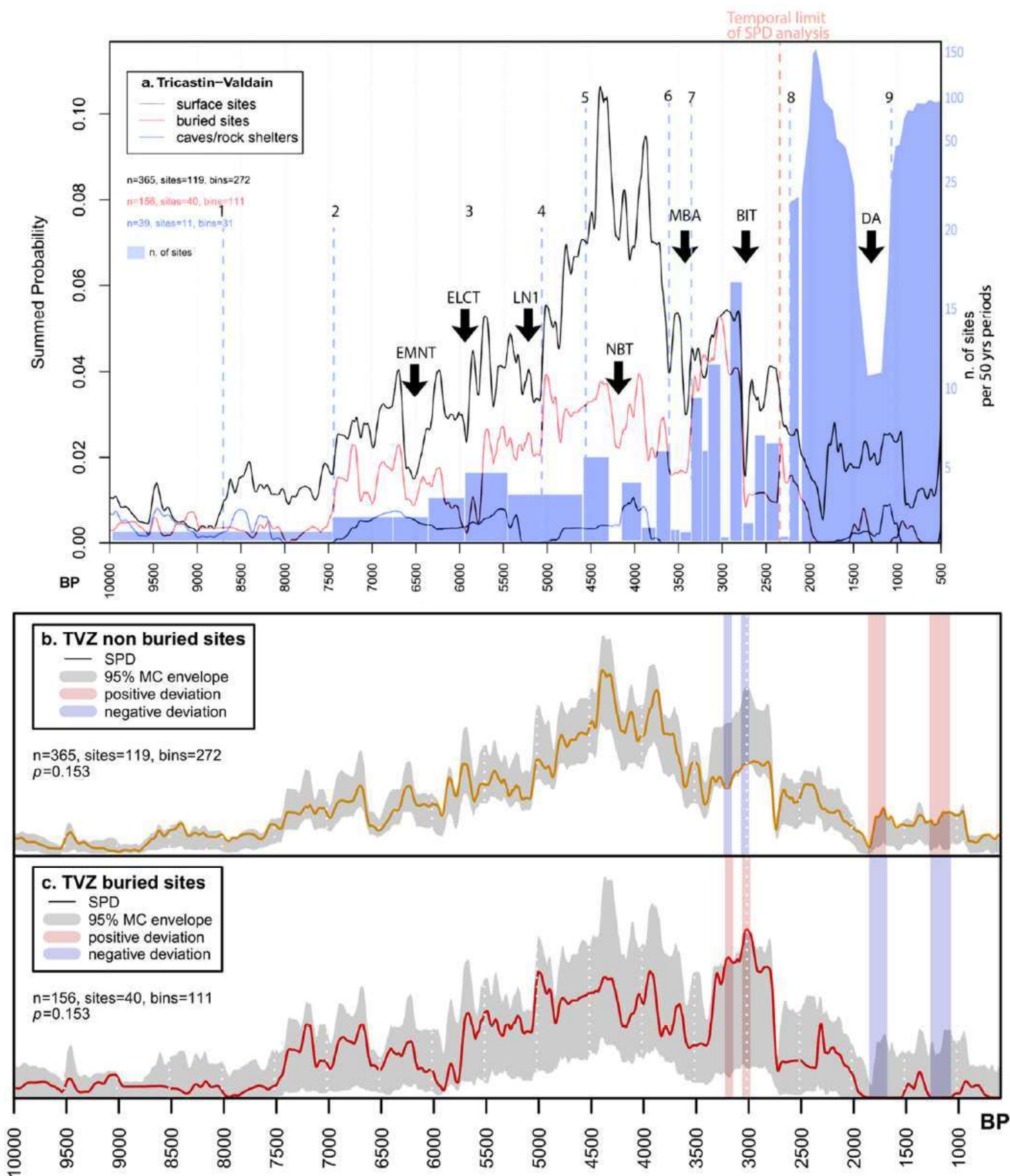

Figure 2. (a) Summed radiocarbon probabilities and site count data for the Tricastin-Valdain area. Dashed lines correspond to significant thresholds. The bar chart represents the raw count of all archaeological sites divided by half-centuries to standardise the number of sites for the longest cultural phases ( $2 / 4$ centuries), except for the historical periods where the continuity of occupation is proven at the 50 year scale; (b) SPD of unnormalised calibrated radiocarbon dates from non-buried sites from the TVZ compared with a $95 \%$ Monte Carlo critical envelope for all TVZ sites produced via permutation of subset dates; and (c) SPD of buried sites from the TVZ compared with the same critical envelope.

Early-middle Neolithic Transition(EMNT), early-late Chassean transition (ELC), late Neolithic(LNT) I period, Neolithic-Bronze transition (NBT), middle Bronze Age period (MBA), Bronze-First Iron Age Transition (BIT) (8th c. BC), and Dark Age period (DA).

valley, which has similar taphonomic conditions to the TVZ, shows a similar SPD pattern, without a marked LN peak and above the overall $95 \%$ confidence interval from 3400 to $2700 \mathrm{cal}$. yr BP (Figures $4 \mathrm{c}$ and $5 \mathrm{c}$ ). It appears that growth of settlement networks in the LBA mainly occurs in the floodplains. The sitecount curves of the three regions, especially BGZ II and III confirm the higher density of the LBA population compared with the late Neolithic, with a maximum centred on $2700 \mathrm{BP}$, but they do not reflect the brief decline at the Bronze-Iron Age transition (2700 cal. yr BP), identified only on the three SPD curves.

From c. 2200 cal. yr BP, all the site-derived proxies rise very steeply to a new peak corresponding to the early Roman period before declining almost as steeply to a trough $c .1200$ cal. yr BP (Figure 5). They then rise again to a peak at c. 800-700 cal. yr BP in BGZ III, not seen in BGZ I and II, where the later peak and decline are probably an artefact of the record. Figure $6 \mathrm{a}$ shows the number of occupations per period calculated as a percentage of the total number of occupations for the timespan from 2750 to 350 cal. yr BP, for the eastern Languedoc survey micro-region, comparing the Archaeomedes-Archaedyn data with our data pattern for the micro-region (see Figure 1 for the location and spatial extent of the archaeological survey). The two patterns are very similar but our data tend to over-represent the earlier periods and under-represent the early Roman and medieval periods. Both 


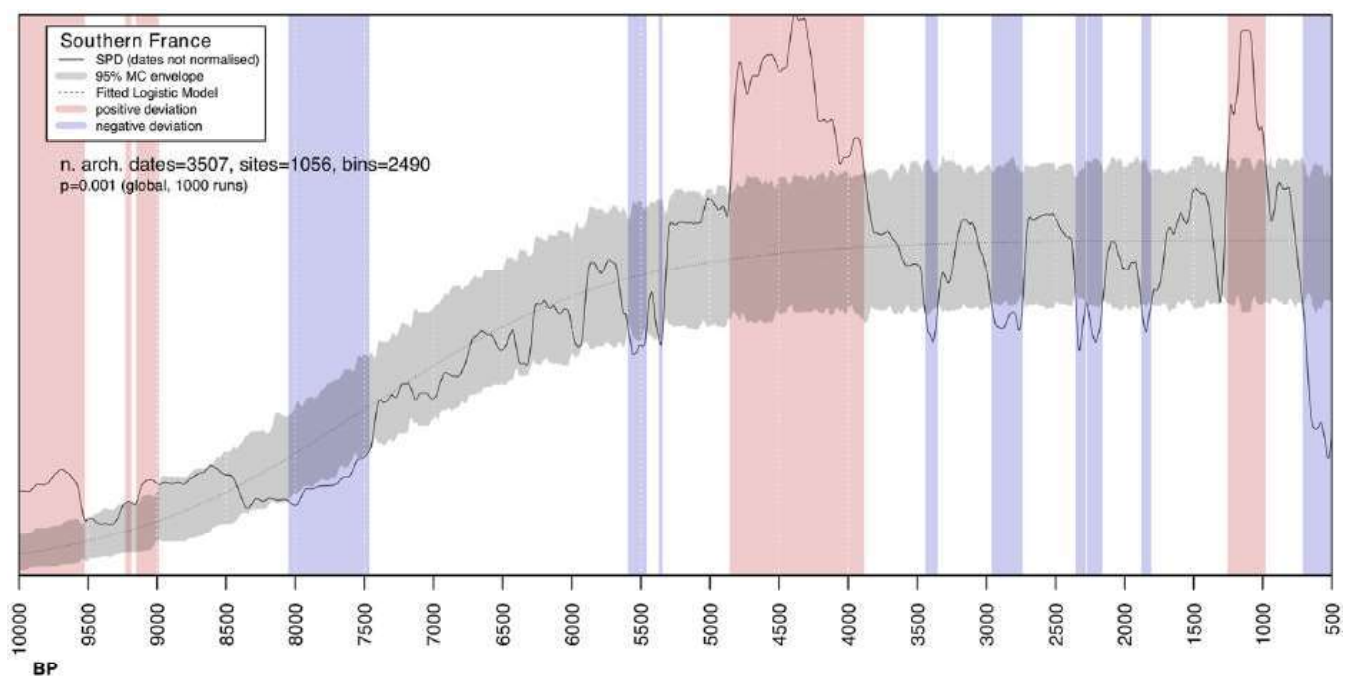

Figure 3. Summed probability distribution of unnormalised calibrated radiocarbon dates from the southern France region as a whole versus a fitted logistic null model ( $95 \%$ confidence grey envelope). Pink and blue shed bands indicate chronological ranges within which the observed SPD deviates positively and negatively, respectively, from the null model.

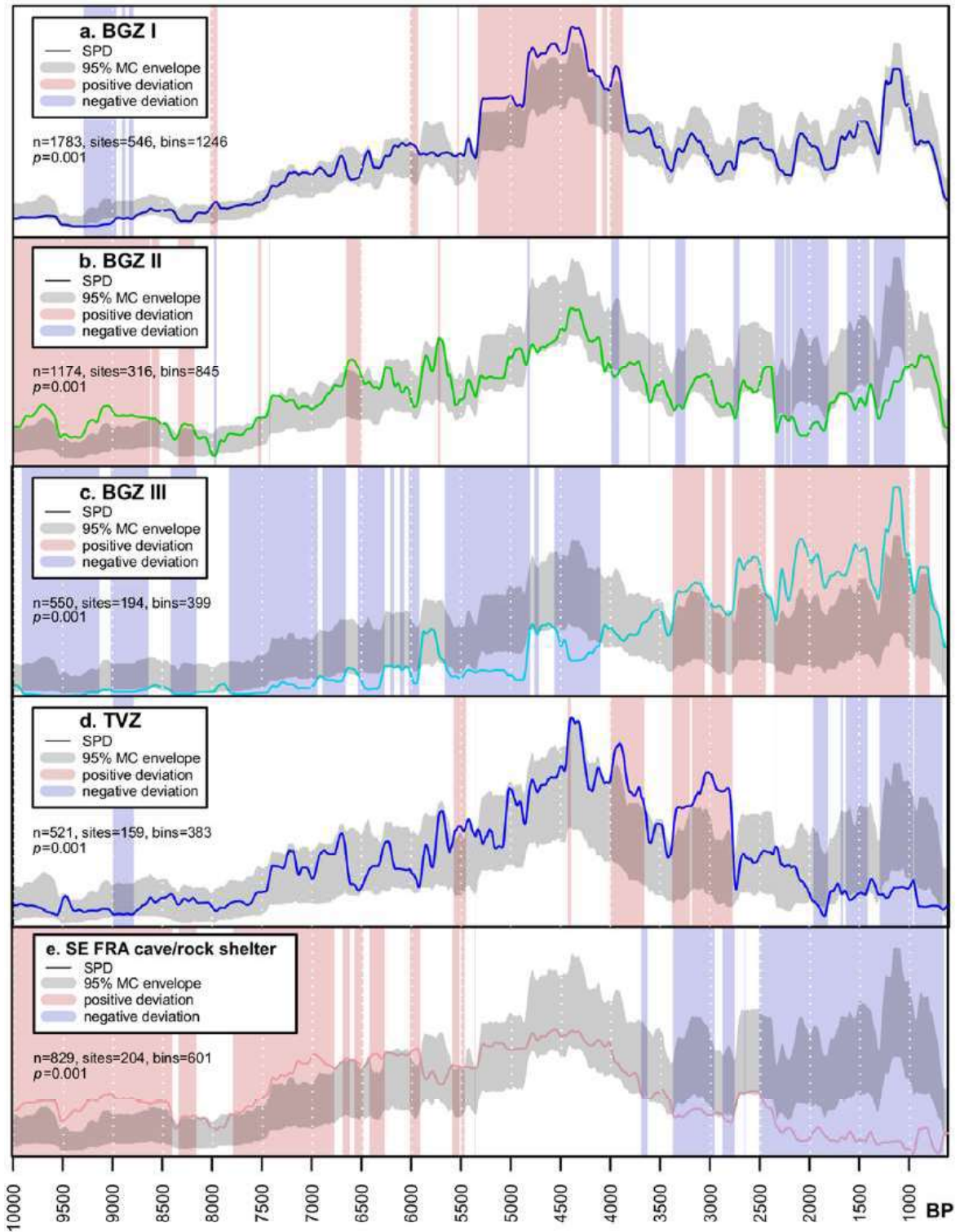

Figure 4. Summed probabilities of subsets of unnormalised calibrated radiocarbon dates compared with relevant $95 \%$ Monte Carlo critical envelopes produced via permutation of subset dates: (a) BGZ I, (b) BGZ II, (c) BGZ III, all against the overall southern France pattern, (d) The TVZ against BGZ I and II and (e) cave and rockshelter sites against overall southern France. 


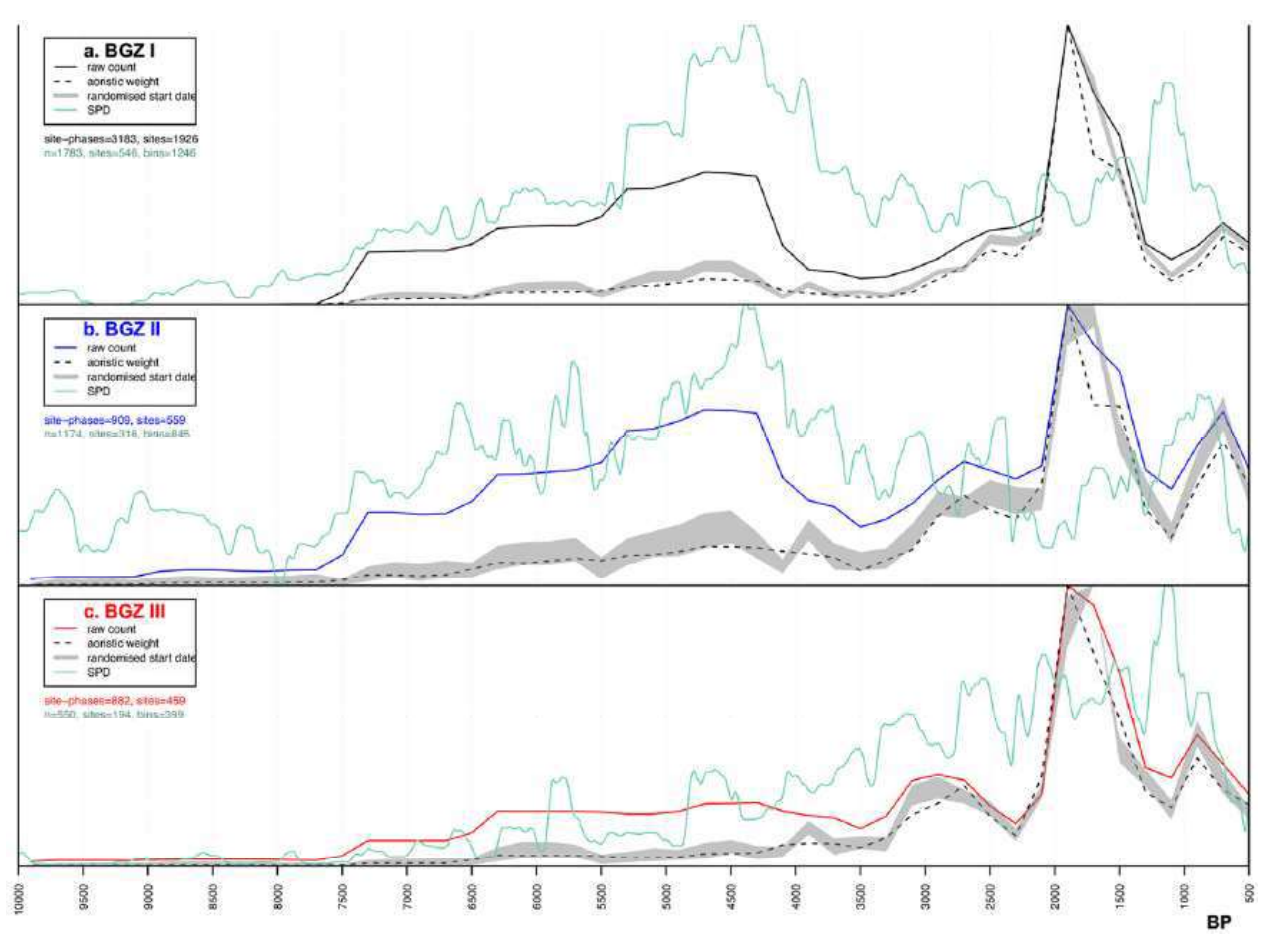

Figure 5. All demographic proxies: (a) BGZ I, (b) BGZ II, and (c) BGZ III. Normalised value on a scale between 0 and I.

databases show the same minimum between 1400 and $1200 \mathrm{cal}$. yr BP. However, if we compare the fluctuations in the cumulative area occupied calculated for the micro-region (ArchaeomedesArchaedyn project), as opposed to the number of occupations, we can see that they are much less marked (Figure 6b), so the count figures are telling us about site dispersal and nucleation as well as about overall density. Similar patterns are seen in the ArdècheTricastin and Etang de Berre micro-region survey areas when the Archaeomedes II and our datasets are compared (not shown), although the number of settlements in the latter dataset for these two micro areas is very small.

\section{Human impact on vegetation dynamics in Southern France}

Pollen results. The cluster analysis results indicate that during the early Holocene (since 11,000 cal. yr BP in the datasets presented here) the landscape of southern France was dominated by pine woods/forest (clusters 4.0 and 5.1) and mesic forest (cluster 8.4) (Figure 7a). These clusters declined from around 8000 cal. yr BP and were replaced by fir forest (cluster 7.0), coniferous forest (cluster 8.2) and deciduous oak woods (cluster 6.1), which initially increased from around 10,000 cal. yr BP. This was then followed by a gradual increase in 7.0 and 8.2 , which, with the exception of cluster 6.1 , peak around $6000 \mathrm{cal}$. yr BP, followed by a gradual decline and replacement by beech woods (cluster 8.3 ) and alder woods (cluster 8.1) until 1500 cal. yr BP. A more recent increase in deciduous oak parkland (cluster 6.2), pasture/wetland (cluster 3.0) and, to a lesser extent, steppe parkland (1.3) and sclerophyllous parkland (1.1) is also evident, and in the modern landscape pine forest (cluster 4.0) and pine woods (cluster 5.1) increase in abundance.

When split into the three biogeographic zones, regional dissimilarities are evident with regard to the dominant vegetation types and their trajectories of change. The coastal Mediterranean area (BGZ I; Figure 7b) shows greater abundance of deciduous oak woods (cluster 6.1), the first appearance of deciduous oak parkland (cluster 6.2) (from 7000 cal. yr BP) and pasture/wetland (cluster 3.0) from $9500 \mathrm{BP}$, well before the beginning of the Neolithic. Fir forest (cluster 7.0) is not represented in this region and conifer forest (8.2) and beech woods (8.3) are barely represented. The supra-mediterranean region (BGZ II; Figure 8a) shows the same patterns of vegetation change as the combined record for southern France, which is not surprising as there are a greater number of pollen sites in this region resulting in BGZ II having a greater overall influence on the patterns observed, with fir forest (cluster 7.0) that is well represented throughout the mid-Holocene and less mesic forest (cluster 8.4) in the early Holocene. BGZ III (MRV; Figure 8b) is the most distinctive region, with less diversity in vegetation cluster groups overall. This may be reflective of the vegetation structure of this region, but is also the result of the smaller number of pollen sites in BGZ III, which means there is less overall diversity captured by the datasets. The early Holocene is dominated by mesic forest (8.4), which declines around 7000 cal. yr BP and is replaced by fir forest (7.0), then alder woods (8.1) and beech woods (8.3) from 4500 BP. Finally, it is replaced by deciduous oak parkland (6.2) from $2000 \mathrm{cal}$. yr BP and pasture/wetland (3.0) since $1400 \mathrm{cal}$. yr BP. Pine steppe (cluster 5.2), deciduous oak parkland (6.2) and coniferous forest (cluster 8.2) are abundant in the modern landscape.

Each vegetation cluster is distinctive but the same pollen taxa can be found in multiple clusters, within different distinct assemblages. As an additional useful assessment of major changes in the vegetation patterns over time, indicator groups have been calculated using pollen percentage data for each region (Figure 9). Some of these represent pollen groups associated with human land use, such as pastoral indicators, which increased from around $2500 \mathrm{cal}$. yr BP for all regions combined. The API steadily increases from 5500 cal. yr BP with a marked rise around 2000 BP. The OJC index also increases after 2500 cal. yr BP, which may indicate increasing human impacts since this time. The \%AP declines steadily from 4500 cal. yr BP with a more marked decrease from 2500 cal. yr BP. The increasing OJC index during this time illustrates the changing composition of AP. When split into separate regions (Figure $9 \mathrm{~b}$ ) similar patterns are shown in the Mediterranean coastal area (BGZ I) to the record for all regions combined, although they are slightly more noisy, which results from the smaller number of sites in the sub-regions. The supraMediterranean region (BGZ II) shows similar overall patterns although the API and pastoral indicators indicate an earlier peak 


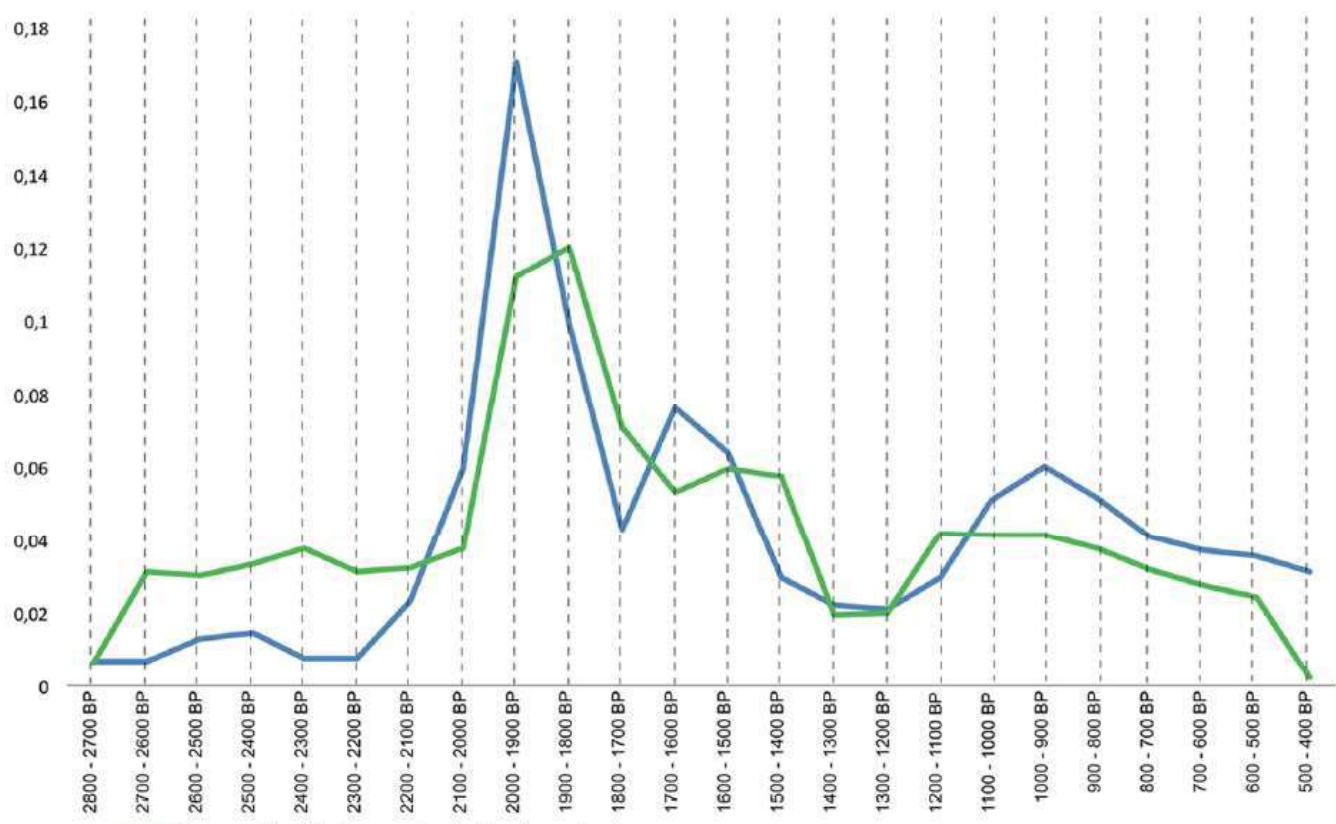

a $\%$ occupation (Archaeomedes-Archaedyn project)

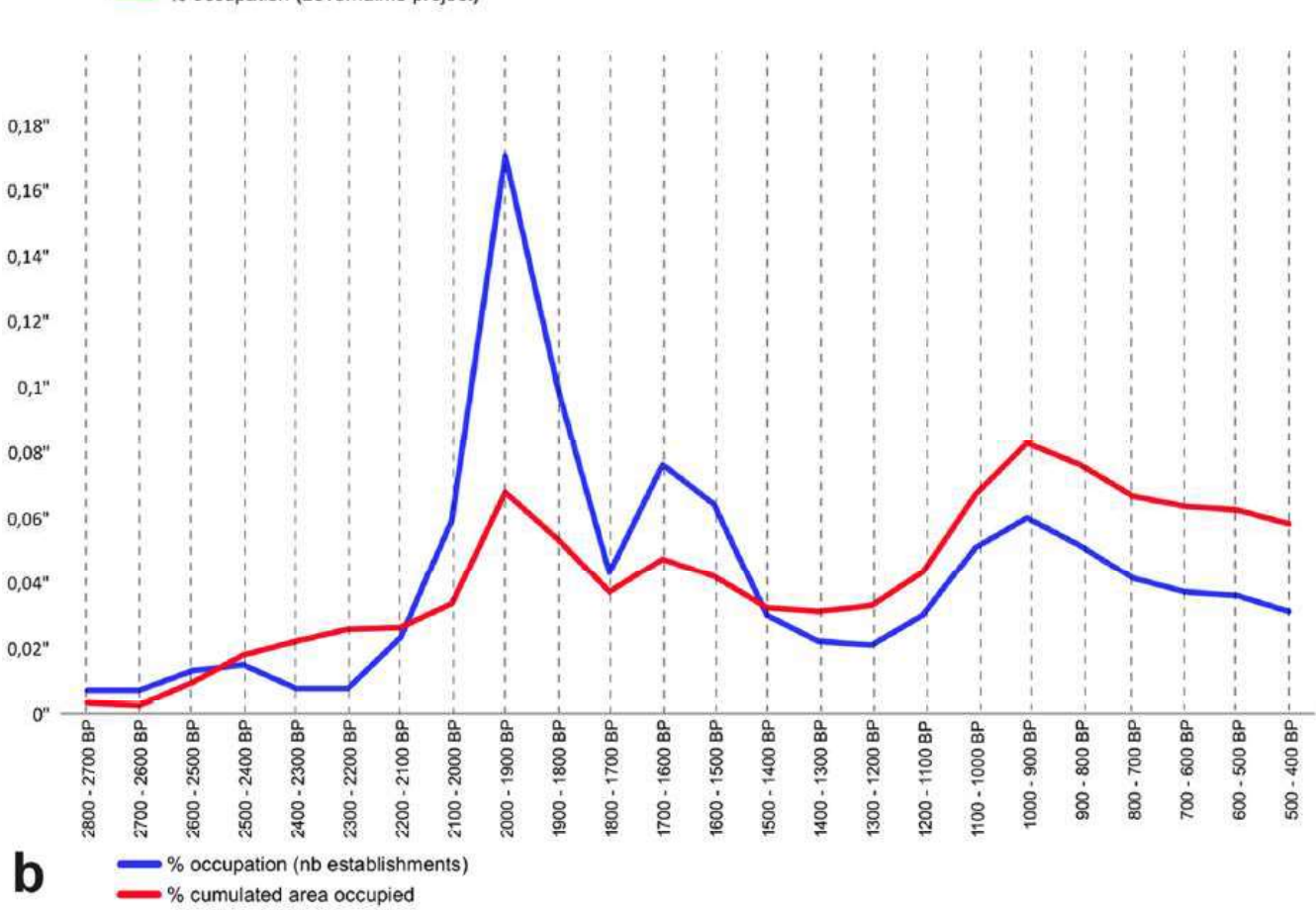

Figure 6. (a) Site count data for the Eastern Languedoc intensive survey area, comparing the percentage of occupations in each 100 year phase from the Archaeomedes-Archaedyn surveys with the percentage from the same area in the Leverhulme project database; (b) Site count data for the Eastern Languedoc intensive survey area, comparing the percentage of occupations in each 100 year phase with the percentage of the total area occupied.

All data from the Archaeomedes-Archaedyn surveys.

around $8000 \mathrm{cal}$. $\mathrm{yr} \mathrm{BP}$, and then steadily increase from around 4000 cal. yr BP. The OJC index increases from $2500 \mathrm{cal}$. yr BP with a recent decline in the last 400 years in both the supra-Mediterranean and middle Rhône regions (BGZ II and III), whereas OJC remains high until the modern period in the coastal Mediterranean region (BGZ I).

\section{Correlation between inferred population and pollen- based indices}

Tables 3-6 show the Spearman's correlation between the pollenbased indices of human impact and the demographic proxies for southeastern France as a whole and for each of the biogeographic zones (see Figure 9 for a visual comparison). The correlations with the radiocarbon record only cover the period up to $2400 \mathrm{cal}$. yr BP because after that date it is no longer a satisfactory demographic proxy. All the different demographic proxies are highly correlated with one another and also have generally high negative correlations with the AP values. The different human impact proxies are all quite strongly positively correlated with one another, again as one would expect. For southern France as a whole, the highest correlations with the demographic proxies are shown by the OJC and RHAPI values. This also true for BGZ I, with RHAPI higher than OJC. In BGZ III there are equally high correlations between the demographic proxies and OJC and RHAPI, though the former is less obvious visually (Figure 9b). 
(a)
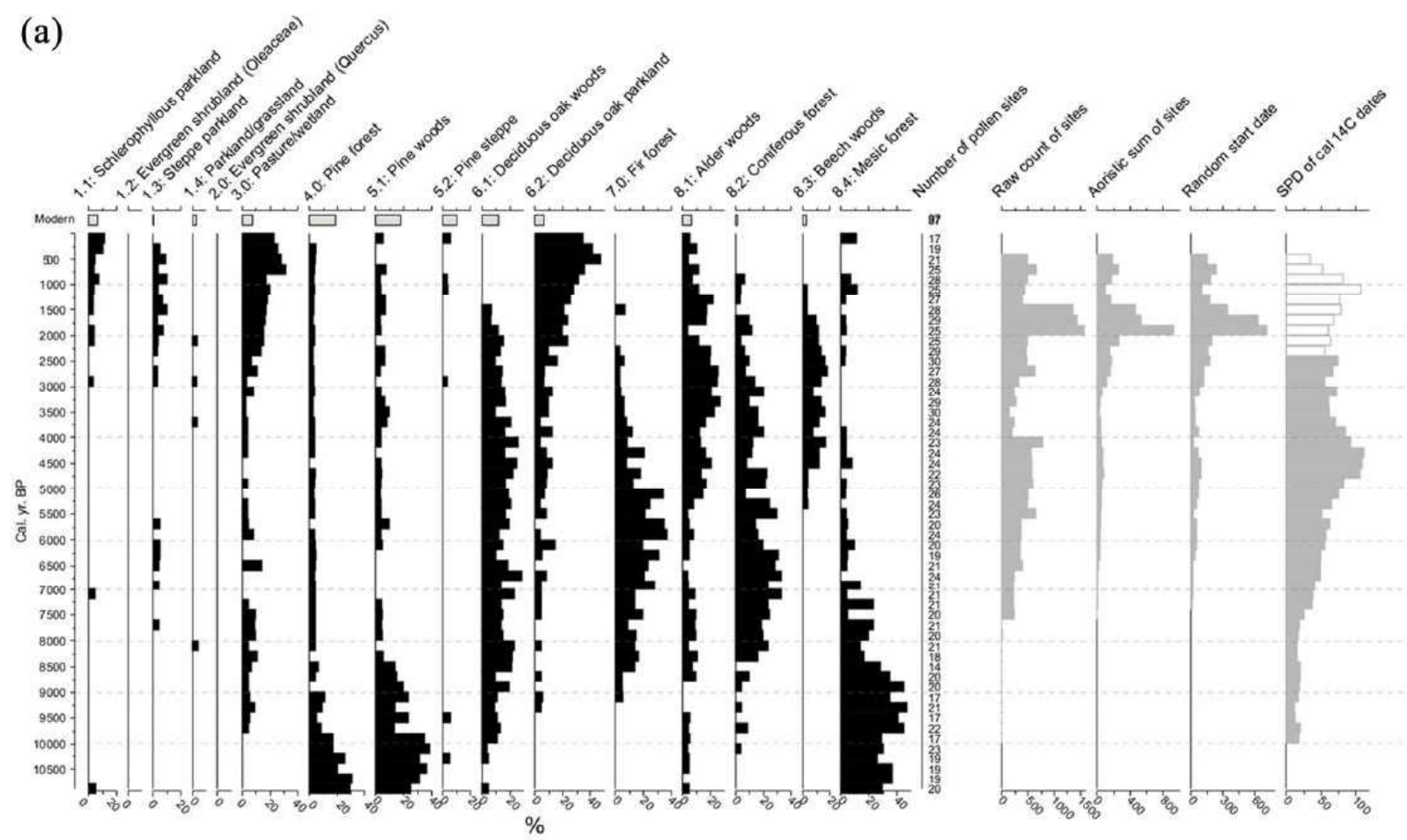

(b)

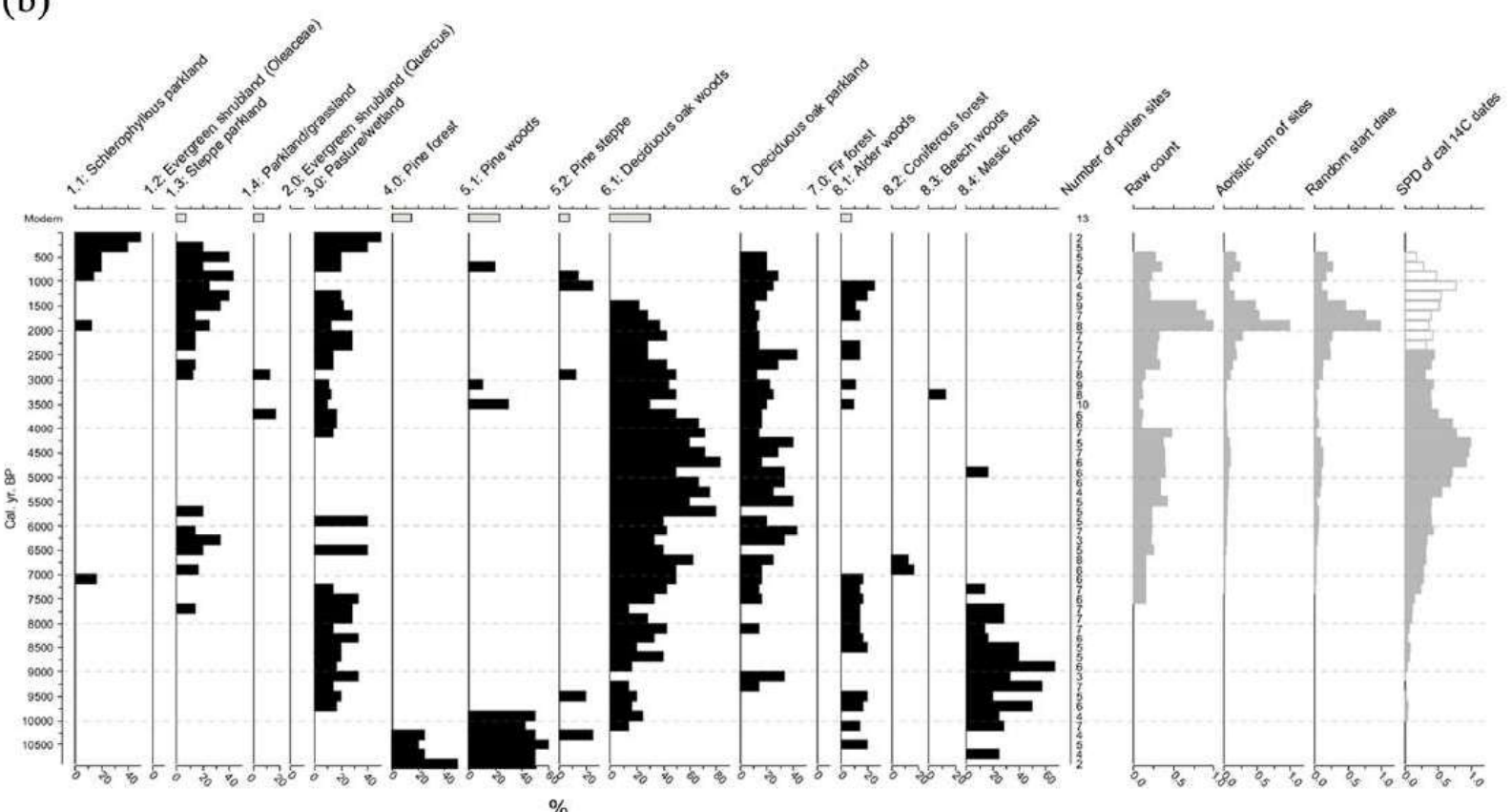

Figure 7. Pollen-inferred vegetation cluster groups and demographic proxies: (a) Southern France all regions combined and (b) BGZ I.Time windows for later periods where the SPD is no longer a reliable proxy are shown in white.

BGZ II, however, is different. Here the correlations between RHAPI and the population proxies are weak, and in two of the four cases not significant. The correlations with OJC remain high, especially for the transformed site count data (AW and random start dates), which cover the whole of the chronological range, suggesting that for this zone the tree crops are especially important.

\section{Palaeoclimate}

Ideally, the long-term record of human demography in south-eastern France could be compared against the record of regional climate variations as an alternative potential driver of land cover change. However, this is made more difficult because of a lack of palaeoclimate data within the region. There are reconstructions of climate from pollen evidence in Mediterranean France (e.g. Azuara et al., 2015; Guiot and Kaniewski, 2015; Jalut et al., 2009; Peyron et al., 2017) and also from fluvial environments (Bravard et al., 1997), but these data cannot then be used to establish the consequences for land cover without circular reasoning. For this reason, southern France is the only case study region in this special issue for which a hydro-climate reconstruction has not been possible (see Finné et al., in press). Instead, we make a brief summary here of the available climate records in south-eastern France and adjacent regions, other than from palynology and fluvial geomorphology.

The Grotte de Clamouse, west of Montpellier and lying at $75 \mathrm{~m}$ a.s.1., has a speleothem stable isotope record spanning the whole Holocene (McDermott et al., 1999). $\delta^{18} \mathrm{O}$ shows a narrow range of isotopic variation between -4.5 and $-5.5 \%$ during the last 11,000 
(a)
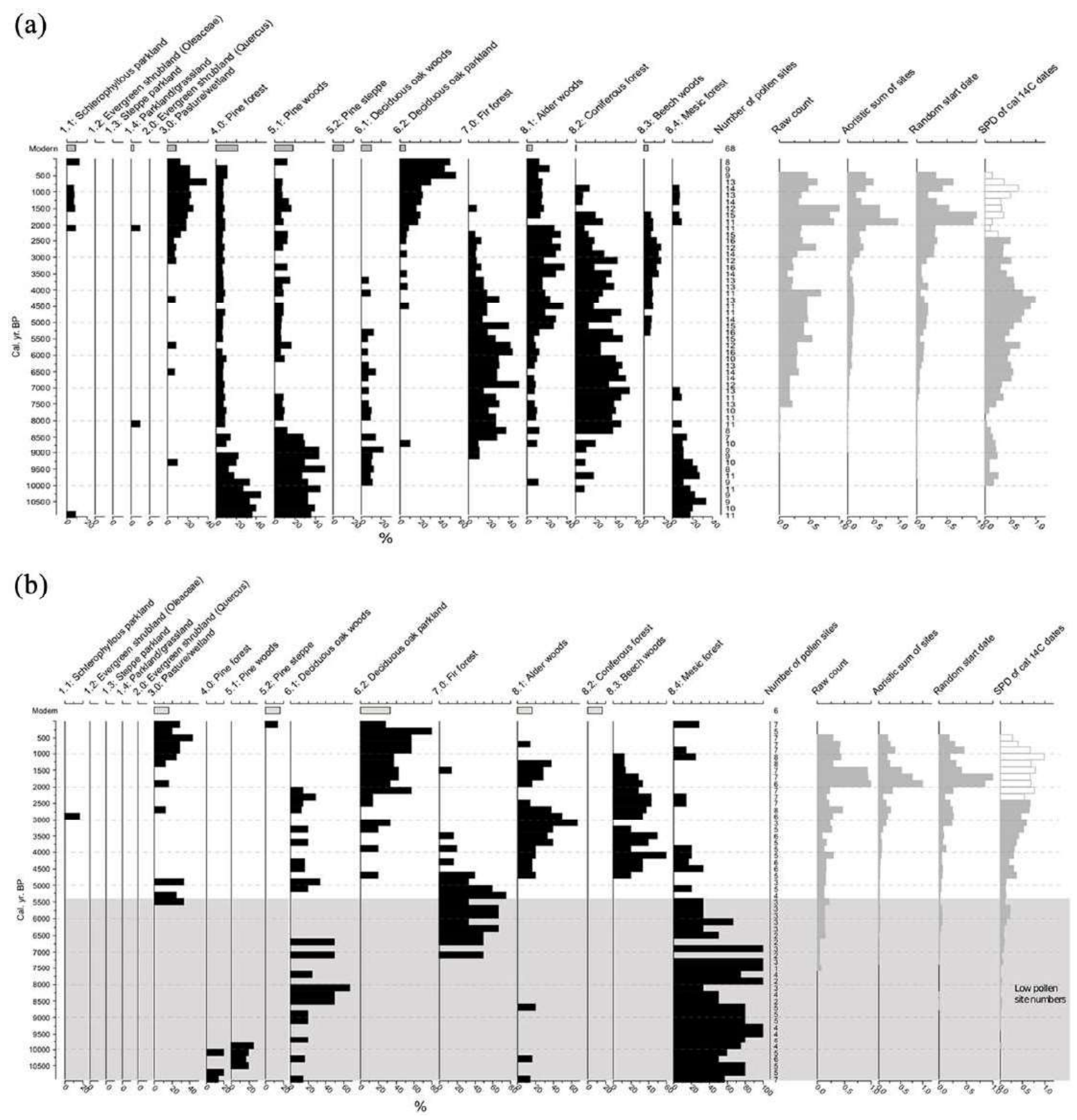

Figure 8. Pollen-inferred vegetation cluster groups and demographic proxies (a) BGZ II and (b) BGZ III.Time windows for later periods where the SPD is no longer a reliable proxy are shown in white.

years, with minimum values between 4000 and 1600 cal. yr BP. $\delta^{13} \mathrm{C}$ displays a much larger range $(-7.5$ to $-11 \%$ ) over this time, with progressive isotopic depletion prior to $\sim 2000$ cal. yr BP, followed by a reversal of this trend in the last two millennia. The authors inferred that for $\delta^{18} \mathrm{O}$, temperature rather than precipitation was the main climatic control, while for $\delta^{13} \mathrm{C}$ changes in vegetation and soil carbon must have been key controls. In the Alpes de Haute Provence, Lac Petit has been studied for pollen, diatoms and geochemistry (Cartier et al., 2015). This small lake near to the upper tree line shows an important regime shift at $\sim 4000$ cal. yr $\mathrm{BP}$, which the authors inferred was triggered by the $4.2 \mathrm{ka} \mathrm{BP}$ abrupt climate event. The 4.2 ka climate event is also clearly evident in the speleothem stable isotope record from Renella cave in northwest Italy (Drysdale et al., 2006). In the western French preAlps and extreme southern Jura (BGZIII), transgressive lake levels around 3500 and 2750 cal. yr BP (Cerin-Bourget) favoured the abandonment of lake-dwelling sites during the Middle Bronze Age and at the end of the LBA (Magny et al., 2009), simultaneously with increasing soil erosion, flood frequency and torrential river activity showing increased connectivity with the upper basins
(Arnaud et al., 2005; Berger, 2015; Simmoneau et al., 2013). The lake-level data of Cerin indicate high water levels at 8200/8000, $7500 / 7200,6500 / 6000,5600 / 4800,4200,3900$ and 2700/2200 cal. yr BP(Magny et al., 2011). The Paladru lake shore records transgressive phases around 2600/2500 and $1600 \mathrm{cal}$. yr BP, and 3 important regressive phases around AD 3000-2800, AD 1500 1200 and AD 1050-900 during the Medieval Climate Anomaly (Brochier et al., 2007). Other climate reconstructions for southeastern France have relied on more distant correlations, for example, with the North Atlantic Bond cycles (e.g. Azuara et al., 2015). However, by definition this assumes that climate in this region was controlled primarily by Atlantic-sourced precipitation, rather than southern moisture sources linked to western Mediterranean seasurface temperatures (SSTs), such as Cévenol storms. Alkenonebased SSTs from shallow marine core KSGC-31 in the Gulf of Lions show a decline of $\sim 3^{\circ} \mathrm{C}$ between 5500 and 1500 cal. yr BP, with a partial reversal in the last millennium (Figure 9a; Jalali et al., 2016). Analysis of n-alkanes in the same core show an increase in chain lengths during the course of the Holocene, which has been interpreted as indicating an increasing moisture deficit in 


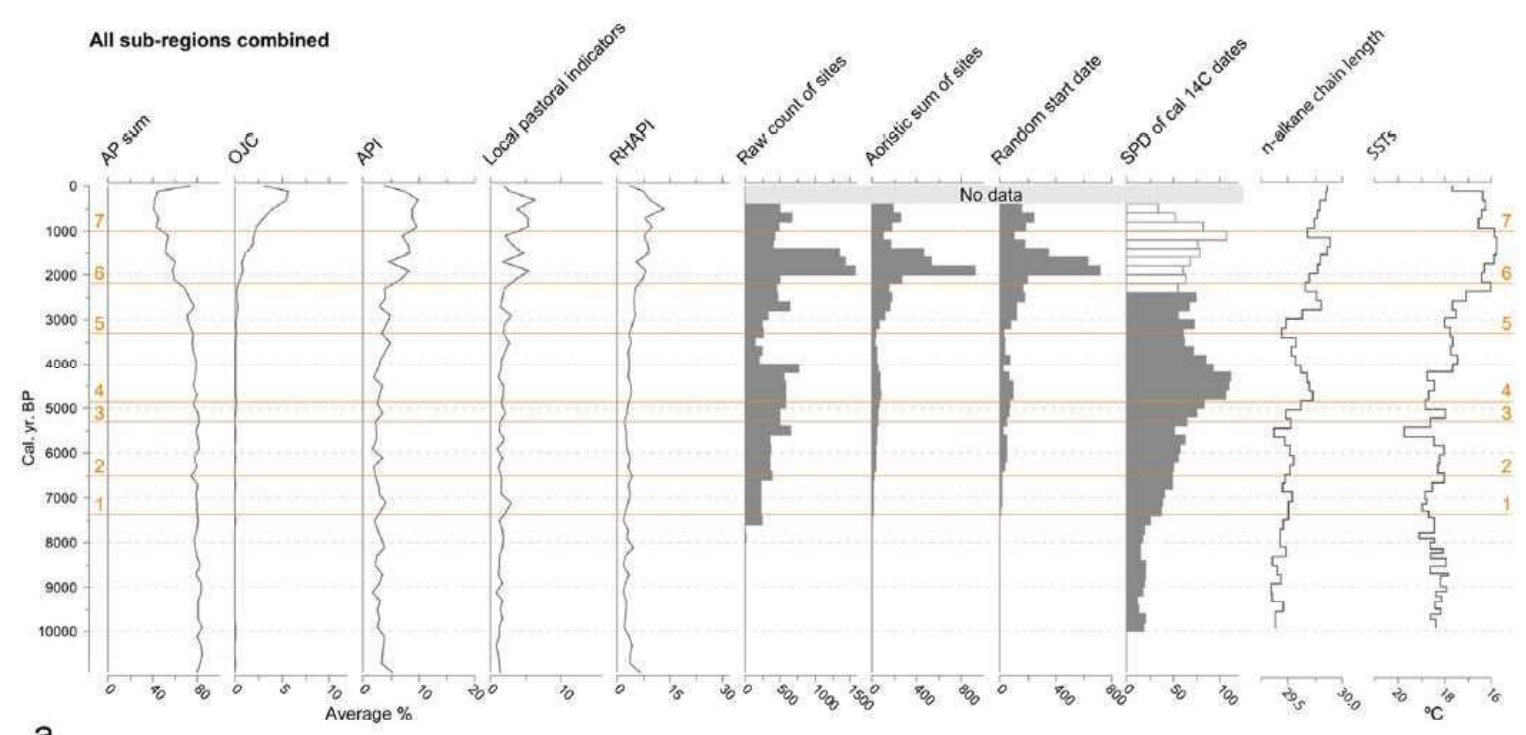

a

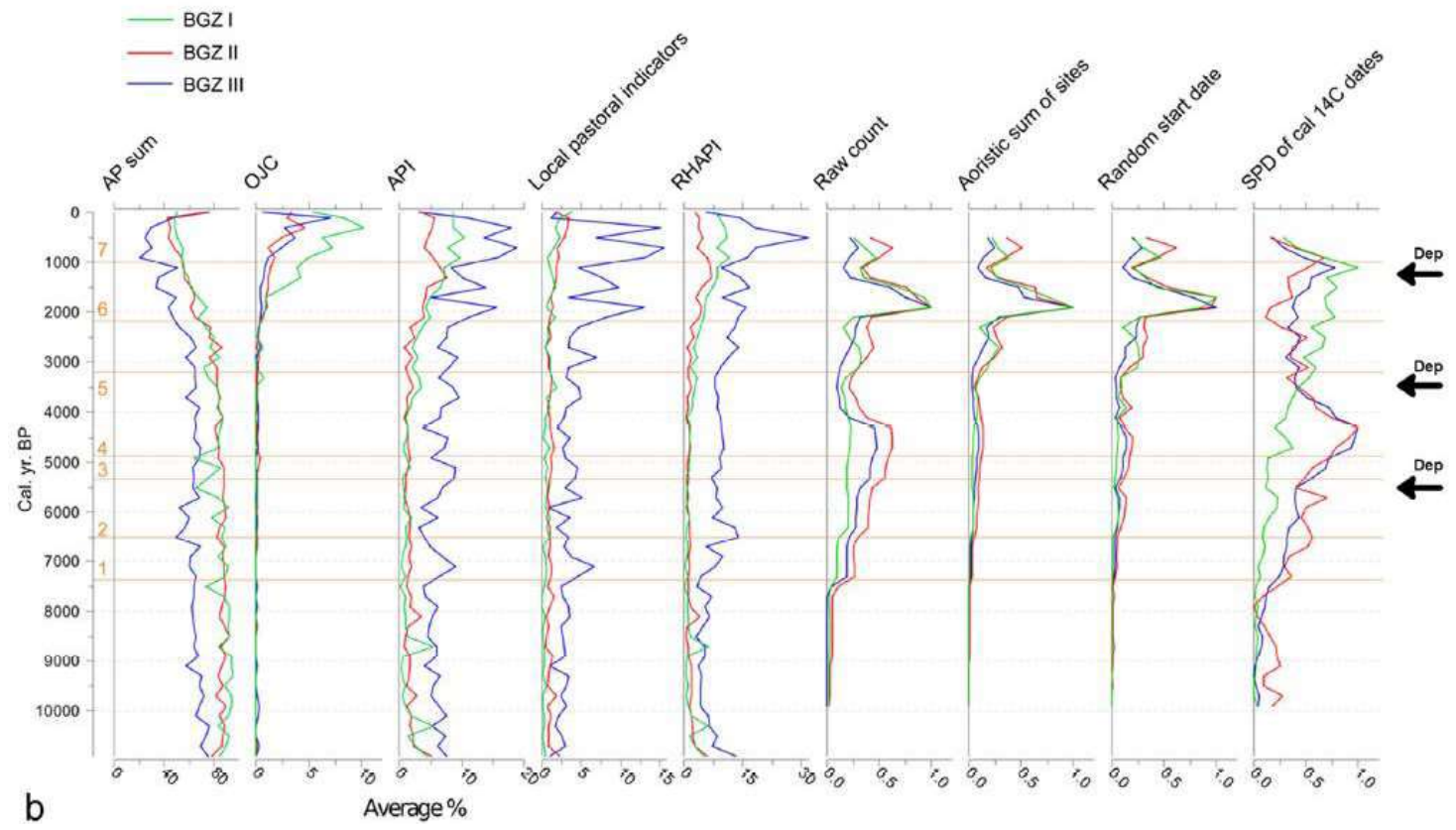

Figure 9. (a) Pollen indicator groups, two climate records from shallow marine core KSGC-3I in the Gulf of Lions (data from Jalali et al., 2016,2017 ), and demographic proxies showing thresholds and depression phases mentioned in the text for Southern France all regions combined; (b) Pollen indicator groups and demographic proxies showing thresholds and depression phases mentioned in the text for the three sub-regions. Time windows for later periods where the SPD is no longer a reliable proxy are shown in white.

the River Rhône catchment (Figure 9a; Jalali et al., 2017). This would have been linked to drier climatic conditions and/or changes in vegetation cover and evapotranspiration, with notable shifts to drier conditions at 5000 and at 3000 cal. yr BP. This appears rather similar to the hydro-climatic trend found in southern and eastern parts of the Mediterranean (Finné et al., in press). In summary, apart from the short-lived dry period at around $4200 \mathrm{cal}$. yr BP, current palaeoclimate data from south-eastern France do not show clear, replicated trends that would allow a direct, within-region comparison with pollen-based land cover in the same way as for archaeologically inferred population.

\section{Discussion: Socio-Environmental trajectories from the early to the late Holocene}

The reading of the various demographic proxy curves identifies a tendency from $7500 \mathrm{cal}$. yr BP for consistent increase in the number of sites and archaeological ${ }^{14} \mathrm{C}$ dates (at least until $4400 \mathrm{BP}$ ), before a long intermediate depression. Globally, despite differences in the size of the archaeological population, we observe a clear synchronism between demographic trends in the three subregions of southern France, including the TVZ dataset, between 10,000 and 500 cal. yr BP. The correlation appears even more robust from 2200 to $1000 \mathrm{BP}$. In the following paragraphs, we present a socio-environmental reading of the data in terms of successive thresholds from the beginning of Neolithisation (threshold 1: 7400 cal. yr BP) until the medieval period (threshold 7: 1000 cal. yr BP) (Figure 9).

The thresholds generally correspond to a significant increase in the various population indicators. They can appear suddenly (e.g. 1, 2 or 6) or represent the starting point of a lasting trend towards a growth in the number of occupations which can culminate 1 or 2 centuries after, especially after periods of partial withdrawal or reorganisation. Their appearance is much more visible in the SPD until the end of the Neolithic. In most cases, these thresholds correspond to rapid changes in at least one of the main agropastoral indicators, to a decline in tree cover or/and to the development of a cluster associated with a characteristic 
Table 3. Matrix of Spearman's Rank Correlation Coefficients (R-values) between the pollen indicator groups and the demographic proxies for the period 10,000-600 cal.yr BP (to 2400 cal.yr BP for ${ }^{14} \mathrm{C}$ SPD) in Southern France.

\begin{tabular}{|c|c|c|c|c|c|c|c|c|c|}
\hline & $A P$ sum & OJC & API & $\begin{array}{l}\text { Local } \\
\text { pastoral }\end{array}$ & RHAPI & $\begin{array}{l}\text { Sites } \\
\text { count }\end{array}$ & $\begin{array}{l}\text { Aoristic } \\
\text { sum }\end{array}$ & Random & ${ }^{14} \mathrm{C}$ SPD \\
\hline AP sum & 1 & & & & & & & & \\
\hline OJC & -0.76 & I & & & & & & & \\
\hline API & -0.78 & 0.62 & 1 & & & & & & \\
\hline Local pastoral & -0.68 & 0.55 & 0.86 & 1 & & & & & \\
\hline RHAPI & -0.92 & 0.72 & 0.79 & 0.65 & I & & & & \\
\hline Sites count & -0.56 & 0.71 & 0.29 & 0.33 & 0.56 & I & & & \\
\hline Aoristic sum & -0.77 & 0.86 & 0.58 & 0.56 & 0.78 & 0.88 & 1 & & \\
\hline Random & -0.78 & 0.84 & 0.63 & 0.61 & 0.81 & 0.81 & 0.98 & 1 & \\
\hline${ }^{14} \mathrm{C}$ SPD & -0.45 & 0.74 & 0.14 & 0.20 & 0.47 & 0.82 & 0.91 & 0.87 & I \\
\hline
\end{tabular}

AP: arboreal pollen; OJC: Olea, Juglans, Castanea; API: anthropogenic pollen index; RHAPI: regional human activity pollen indicators; SPD: summed probability distribution.

Statistically significant values in bold $(p<0.05)$.

Table 4. Matrix of Spearman's Rank Correlation Coefficients (R-values) between the pollen indicator groups and the demographic proxies for the period 10,000-600 cal. yr BP (to 2400 cal. yr BP for ${ }^{14} \mathrm{C}$ SPD) in BGZ I.

\begin{tabular}{|c|c|c|c|c|c|c|c|c|c|}
\hline & $\begin{array}{l}\text { AP } \\
\text { sum }\end{array}$ & OJC & API & $\begin{array}{l}\text { Local } \\
\text { pastoral }\end{array}$ & RHAPI & $\begin{array}{l}\text { Sites } \\
\text { count }\end{array}$ & $\begin{array}{l}\text { Aoristic } \\
\text { sum }\end{array}$ & Random & ${ }^{14} \mathrm{C}$ SPD \\
\hline AP sum & 1 & & & & & & & & \\
\hline OJC & -0.44 & 1 & & & & & & & \\
\hline API & -0.43 & 0.56 & I & & & & & & \\
\hline $\begin{array}{l}\text { Local } \\
\text { pastoral }\end{array}$ & -0.53 & 0.43 & 0.86 & I & & & & & \\
\hline RHAPI & -0.67 & 0.56 & 0.55 & 0.54 & 1 & & & & \\
\hline Sites count & -0.4 & 0.46 & 0.35 & 0.31 & 0.72 & I & & & \\
\hline Aoristic sum & -0.57 & 0.67 & 0.58 & 0.54 & 0.88 & 0.86 & I & & \\
\hline Random & -0.56 & 0.65 & 0.6 & 0.58 & 0.86 & 0.8 & 0.98 & I & \\
\hline${ }^{14} \mathrm{C}$ SPD & -0.08 & 0.49 & 0.35 & 0.16 & 0.70 & 0.82 & 0.88 & 0.86 & I \\
\hline
\end{tabular}

BGZ: biogeographical zones;AP: arboreal pollen; OJC: Olea, Juglans, Castanea;API: anthropogenic pollen index; RHAPI: regional human activity pollen indicators; SPD: summed probability distribution.

Statistically significant values in bold $(p<0.05)$.

Table 5. Matrix of Spearman's Rank Correlation Coefficients ( $R$-values) between the pollen indicator groups and the demographic proxies for the period 10,000-600 cal. yr BP (to 2400 cal. yr BP for ${ }^{14} \mathrm{C}$ SPD) in BGZ II.

\begin{tabular}{|c|c|c|c|c|c|c|c|c|c|}
\hline & AP sum & OJC & API & $\begin{array}{l}\text { Local } \\
\text { pastoral }\end{array}$ & $\begin{array}{l}\text { RHA- } \\
\mathrm{PI}\end{array}$ & $\begin{array}{l}\text { Sites } \\
\text { count }\end{array}$ & $\begin{array}{l}\text { Aoristic } \\
\text { sum }\end{array}$ & Random & ${ }^{14} \mathrm{C} \mathrm{SPD}$ \\
\hline AP sum & I & & & & & & & & \\
\hline OJC & -0.69 & I & & & & & & & \\
\hline API & -0.63 & 0.49 & I & & & & & & \\
\hline $\begin{array}{l}\text { Local } \\
\text { pastoral }\end{array}$ & -0.5 & 0.43 & 0.64 & I & & & & & \\
\hline RHAPI & -0.7 & 0.43 & 0.84 & 0.42 & 1 & & & & \\
\hline Sites count & -0.48 & 0.68 & 0.16 & 0.36 & 0.1 & I & & & \\
\hline Aoristic sum & -0.69 & $0.8 I$ & 0.35 & 0.42 & 0.3 & 0.9 & I & & \\
\hline Random & -0.69 & 0.82 & 0.4 & 0.4 & 0.32 & 0.84 & 0.98 & I & \\
\hline${ }^{14} \mathrm{C}$ SPD & -0.35 & 0.60 & -0.23 & 0.26 & -0.30 & 0.79 & 0.81 & 0.78 & I \\
\hline
\end{tabular}

BGZ: biogeographical zones;AP: arboreal pollen; OJC: Olea, Juglans, Castanea; API: anthropogenic pollen index; RHAPI: regional human activity pollen indicators; SPD: summed probability distribution.

Statistically significant values in bold $(p<0.05)$.

landscape management. In the late Holocene, thresholds 6 and 7 show a much clearer correlation with more anthropogenic reactive landscapes. Short periods of occupation depression are identified between these successive thresholds. They can be very short (a century) or more long-lasting, as in the Bronze Age or early medieval period (Figures 2 and 9). They correspond to fast and significant decreases of the raw count and its derivatives, synchronous or not with the SPD.
Threshold I: 7400 cal. yr BP

The main growth thresholds are found in each of the 3 biogeographic units (Figure 9), from the plains to the foothills of the Mediterranean mountains, around 7500/7400 BP (early Neolithic Cardial). Simultaneous impacts on vegetation are not observed before 7000 cal. yr BP in BGZ 1 (API and RHAPI), which corresponds to the full agropastoral development of the Epicardial (with 
Table 6. Matrix of Spearman's Rank Correlation Coefficients (R-values) between the pollen indicator groups and the demographic proxies for the period 10,000-600 cal.yr BP (to 2400 cal.yr BP for ${ }^{14} \mathrm{C}$ SPD) in BGZ III.

\begin{tabular}{|c|c|c|c|c|c|c|c|c|c|}
\hline & AP sum & OJC & API & Local pastoral & RHAPI & Sites count & Aoristic sum & Random & ${ }^{14} \mathrm{C}$ SPD \\
\hline AP sum & 1 & & & & & & & & \\
\hline OJC & -0.71 & 1 & & & & & & & \\
\hline API & -0.67 & 0.72 & 1 & & & & & & \\
\hline Local pastoral & -0.66 & 0.58 & 0.6 & I & & & & & \\
\hline RHAPI & -0.68 & 0.75 & 0.94 & 0.6 & I & & & & \\
\hline Sites count & -0.79 & 0.82 & 0.67 & 0.65 & 0.67 & 1 & & & \\
\hline Aoristic sum & -0.79 & 0.82 & 0.75 & 0.72 & 0.76 & 0.95 & 1 & & \\
\hline Random & -0.76 & 0.8 & 0.77 & 0.73 & 0.78 & 0.9 & 0.98 & I & 0 \\
\hline${ }^{14} \mathrm{C}$ SPD & -0.65 & 0.60 & 0.56 & 0.62 & 0.60 & 0.87 & 0.95 & 0.94 & I \\
\hline
\end{tabular}

BGZ: biogeographical zones;AP: arboreal pollen; OJC: Olea, Juglans, Castanea;API: anthropogenic pollen index; RHAPI: regional human activity pollen indicators; SPD: summed probability distribution.

Statistically significant values in bold $(p<0.05)$.

the complete Neolithic toolkit) and the appearance of the first real villages from Languedoc to the Middle Rhone Valley (Berger, 2015; Guilaine and Manen, 2005; Perrin et al., 2014). BGZ I clearly records this first agropastoral impact from $7250 \mathrm{cal}$. yr BP with two main peaks of API-RHAPI, associated with a slow decrease of the AP sum (Figure 9). The supra-Mediterranean zone (BGZ II) does not see any particular anthropic impact, whereas a sharp recession of the forest cover (AP sum) in the MRV (BGZ III), centred on 7500 cal. yr BP, curiously does not appear associated with any anthropogenic markers. This signal could then be associated with the abrupt climatic change that peaks between 7600-7300 cal. yr $\mathrm{BP}$ in the region (Berger et al., 2016) and whose effects on the central-European vegetation are proven (Davis et al., 2003).

\section{Threshold 2: 6500/6300 cal. yr BP}

This increase in settlement density corresponds to the Chassean period, with two SPD peaks in BGZ II-III and the TVZ dataset corresponding, respectively, to its early (6300 cal. yr BP) and late (5800/5700 cal. yr BP) phases (Figure 9). In Languedoc and in the MRV, the density of sites and the presence of vast open-air sites on quaternary terraces show the dynamism of this period. Archaeological, zoological, botanical and geoarchaeological data illustrate a rather pastoral culture (Beeching et al., 2000; Bréhard et al., 2010); caves are mainly used as stabling areas for ovicaprid herds (Argant et al., 1991; Brochier et al., 1999; Thiébault, 2005). Between 6500$6300 \mathrm{cal}$. yr BP, the first forest clearings are identified in BGZ I and II (AP sum) with an increase in RHAPI, and again around $5800 \mathrm{cal}$. yr BP in BGZ I. At the southern regional scale, steppe parklands and pasture/wetland areas appear. These regional vegetation tendencies confirm the Chassean system of landscape management, associated with a dehesa-like landscape, which permitted a sustainable use of the resources for nearly a millennium (Delhon et al., 2009).

The post-Middle Neolithic occupation depression: 5550/54005300 cal. yr BP. The low number of known sites at the final Chassean-late Neolithic transition 1 (5550-5300 cal. yr BP), seen in the RSD and SPD curves of BGZ II-III, supports past interpretations of a regional demographic decline during a period that is still poorly defined culturally (Beeching, 2002; Lemercier, 2007). Few pollen indicators reflect this possible cultural withdrawal in the three BGZs, but all anthropic markers are low and deciduous oak woods seem to recover after a decline during the Chassean period. The API and RHAPI are at their minimum (Figure 9).

\section{Threshold 3: 5300 cal. yr BP}

This corresponds to the first abrupt settlement increase of the late Neolithic (5300 cal. yr BP), seen in all demographic markers in
BGZ I and II, and with a slight delay in the TVZ dataset (Figure 2; 5050 cal. yr BP). It is associated with the growth of the Ferrières, Fraischamp and Couronnien groups from 3300/3200 BCE in the Provencal, Languedoc and Rhône domains. It is not seen in BGZ III, whose dynamics at this time are related to those of the more central-European regions. In BGZ I, API, OJC and Olea increase from $5300 \mathrm{BP}$. In BGZ II, most anthropic indicators increase simultaneously from $5250 \mathrm{BP}$ (OJC, API and RHAPI) and in BGZ III despite a sharp and significant fall in AP sum, centred on 5500 BP, the anthropic indices are restricted (Figure 9).

\section{Threshold 4: 4850 cal. yr BP}

This continues the increase from threshold 3 showing an impressive maximum of sites (RC) and ${ }^{14} \mathrm{C}$ dates (SPD). Languedoc, the Gulf of Lions coastline and Provence (BGZ I) form a hot spot of human settlement during the 5th millennium BP indicating probable population growth in geographic sectors little occupied until then (limestone scrubland and mountain) (Carozza et al., 2005; Lemercier, 2007; Loison et al., 2011). The most significant evidence is the increase in large enclosed settlements in plains and coastal areas during the late Neolithic II (4750 cal. yr BP) and III (until 4250/4150 cal. yr BP). The onset of this human pressure on the landscape corresponds to a period of consolidation (4450 4250 cal. yr BP), an important segmentation of space, and the development of specialisation strategies, for example, in copper metallurgy (Carozza et al., 2005, 2015) Concentrated phases of occupation in the hilly areas involve repeated impacts on vegetation (perceived in AP sum, OJC, OJCV, API and RHAPI of the three BGZs). The deciduous oak forest cluster culminates towards $4500-4300 \mathrm{BP}$, and confirms the human forcing in the hilly areas and the influence of pastoralism. At the same time, there is a rapid decline of subalpine fir stands in favour of alder and beech woods.

The post-Neolithic multi-century occupation depression: 4300 14000-3300/3200 cal. yr BP. The abrupt reversal of the AW, RSD and especially the RC curve just after $4400 / 4300$ cal. yr BP in BGZ I and II is impressive, with a two-thirds decrease in RC site density (Figure 5); it is seen slightly later in the SPD. The TVZ data illustrate at the same time (around $4250 \mathrm{cal}$. yr BP) the abandonment of the sites of the local Bell Beaker culture and an archaeological hiatus of about a century until the emergence of the EBA around 4150 cal. yr BP (Berger et al., 2007; Carozza et al., 2015). Here, the SPD and buried sites curves confirm the simultaneity of the phenomenon (Figure 2). This regional trend reversal may be linked to the $4.2 \mathrm{ka} \mathrm{BP}$ abrupt climate change detected in the lakes and fluvial archives at the regional scale (Arnaud et al., 2008; Berger, 2015; Magny et al., 2011). The SPD and RC/RSD indicators reveal that the abandonment does not 
continue beyond $4100-4000$ cal. yr BP in the three BGZs nor in the TVZ, where a reoccupation of the floodplains is associated with villages and groups of storage pits on excavated sites (Berger et al., 2007). Compared with the Bell Beaker/Fontbouisse maximum, the number of EBA 1 settlements is low. This period is considered as a reorganisation phase around 4100-3850 cal. yr BP (Carozza et al., 2015; Vital et al., 2014). The attraction of intermediate areas (Auvergne medium-elevation mountains), and of high mountains (Pyrenees, northern and southern Alps) causes a reorganisation of settlement around pastoral and hunting activities (Marguet et al., 2008; Walsh et al., 2006) or mining (Bailly-Maitre et al., 2008). This regional reorganisation could have had an impact on the soil and vegetation cover in partially abandoned low alluvial plains and northern Mediterranean coastal areas.

All the data signal a long slow decrease of demographic indicators until shortly after $3500 \mathrm{cal}$. yr BP, when the trend reverses, to peak during the LBA around $3200 / 3000 \mathrm{cal}$. yr BP (SPD curve) and a little later around 2900/2700 cal. yr BP (RC and AW curves). This long post-Neolithic quasi-millennial demographic depression has been discussed in the MRV, where more detailed information reveals a succession of drops in human impact with rhythms of 1 to 2 centuries, with a maximum decrease during the Middle Bronze Age (Figure 2, Berger et al., 2007). The occupation of karstic caves/rock shelters then increases in the Northern Alps (Marguet et al., 2008), in the canyons of the Rhône (Donzère, Drôme), Ardèche, Cèze and Gard rivers (Vital, 1990, Berger et al., 2000). Its imprint is not very visible in the synthetic pollen diagrams (slight recovery of deciduous oak and coniferous wood and especially beech woods in BGZ III, and corresponds to a synchronous drop in anthropogenic indicators in BGZ II between 4000-3700 cal. yr BP). Locally, strong reafforestation has been repeatedly identified between the EBA 2 and the beginning of the LBA (3900-3300 cal. yr BP) (Berger et al., 2000, 2007; Delhon and Thiébault, 2008; Martin and Magnin, 2002; Pétrequin and Weller, 2007; Richard and Gauthier, 2007).

\section{Threshold 5: 3300 cal. yr BP}

This demographic pressure rises from 3300 , but culminates during the Bronze Final IIb phase (3100-3000 cal. yr BP) (Figure 5), associated with the concentration of large villages of several hectares in the MRV floodplains (Billaud, 1999) and a significant increase in occupied surface areas, even compared with BFIIIB, whose absolute number of sites is nevertheless higher (Berger, 2015). The distribution of Bronze Final IIIB sites in all the landscape units of the MRV, associated with the presence of groups of storage pits, shows the degree of human pressure on soils at this time (Berger et al., 2007). From the north of BGZ III to the coastal Mediterranean (BGZ I), the BFIIB and BFIIIB periods are associated with increased settlement density (Lachenal, 2012; Treffort, 2005). This period does not record a real vegetation change before 3000 cal. yr BP where at the regional scale cluster C1, C4 and C7 indicators appear and the API and RHAPI increase (Figures 7-9). Cluster 8 (pasture/wetland) increases from $3200 \mathrm{cal}$. yr BP and the AP sum decreases from 3000 cal. yr BP. In BGZ I, the main impact is centred on 3000-2700 cal. yr BP (peak of API-RHAPI, followed by peaks of Olea, OJC and OJCV), as in BGZ II, with a clear decrease in the AP sum.

Archaeobotanical macroremains testify to the existence of fairly permanent and intensive agriculture at this time (Bouby, 2010). In BGZ III, the agropastoral impact is identified earlier, from 3400/3300 cal. yr BP (API, RPI, OJC and AP sum (Figure $9)$ ), in good agreement with the demographic data and with the settlement and economic dynamics to the north (Franche-Comté), which indicate a restart of the anthropic pressure at the end of the middle Bronze Age (Pétrequin and Weller, 2007).

\section{Threshold 6: 2200 cal. yr BP}

The most important peak in occupation density begins around 2150 cal. yr BP, and culminates $1950-1850$ cal. yr BP (Figure 9) (Archaeomedes, 1998; Favory and Fiches, 1994; Van der Leeuw et al., 2003, 2005). The site densities decrease from the 2 nd century $\mathrm{CE}$ and continue slowly downwards until a brief respite in this trend in the $c .1700-1500 \mathrm{cal}$. yr BP well identified by the AW curve in BGZ I and II, in the TVZ, and by a new dynamism in Languedoc's agrarian habitat (Figure 6). Decline continues more abruptly from $1500 \mathrm{cal}$. yr BP to reach a minimum settlement density (c. 1100 cal. yr BP). As noted above, comparison with the results for the period $2750-4350$ cal. yr BP from the Archaeomedes and Archaedyn micro-regional survey areas within BGZ I shows that they match well, while tending to over-estimate the earlier periods and underestimate the Roman peak.

The work carried out as part of the Archaeomedes project showed that variations in the number of sites (Figure 6a) were strongly linked to changes in land use patterns. For the period from 2750 to $350 \mathrm{cal}$. yr BP, the cumulative area occupied by the sites (Figure 6b) shows a much more regular demographic growth trend. The peak effects, around $2500 \mathrm{BP}$ (identified in the microregional curve) but especially between 1950 and $1850 \mathrm{BP}$ are linked to an explosion in the number of small dwellings and outbuildings that were later abandoned, reflecting a restructuring of the settlement system at a time when population was growing slowly (Archaeomedes, 1998; Brun and Congès, 1996; Favory et al., 2011; Raynaud, 2003; Schneider et al., 2007; Van der Leeuw et al., 2003, 2005). This widespread phenomenon (Bertoncello et al., 2012) is closely related to the region's incorporation into the Roman Empire, which had a profound impact on settlement patterns and landscapes resulting from the unprecedented economic development of Mediterranean exchanges. This involved new forms of production including commercial agriculture, as well as new consumption patterns (Archaeomedes, 1998; Durand and Leveau, 2004; Garcia and Isoardi, 2010), not simply population increase.

Human impact is evident in the simultaneous development of a majority of anthropic pollen clusters (Figures 7-9) from 22502200 cal. yr BP, which appear mostly continuously from this time onwards (sclerophyllous parkland, steppe parkland, pasture/wetland, deciduous oak parklands, Olea, OJC, OJCV, API and RHAPI). Then we observe the rapid decrease of deciduous oak woods (around 1500 cal. yr BP), an abrupt clearing of the alder woods (centred on 2000 cal. yr BP) related to the exploitation of gallery forests and wetlands, and the disappearance of fir woods (Figures 7 and 8). The spread of hydraulic systems then ensures the drainage of a large part of the Rhône wetlands, allowing the expansion of cultivated land and the intensification of crops and fodder (Berger, 2015; Bernigaud et al., 2014). These signatures reveal, at the scale of the large Roman province of Gallia Narbonensis, a commercial agricultural exploitation (vineyards and orchards) which affects all the bioclimatic zones up to the midmountains and results in an unprecedented scale of human land use (Berger and Bravard, 2012; Leveau, 1998). Quantitative sediment budget studies (Notebaert and Berger, 2014) document a major peak in sedimentation (see Walsh et al., in press).

The early medieval settlement depression: 1300-1200 cal. yr BP. The second rupture observed occurs $c$. 1300-1200 cal. yr BP after a slow spatial reorganisation of the settlement system from 1600 cal. yr BP, from a floodplain distribution to a concentration on hills and plateaus in the MRV and BGZ III (Berger et al., 2007). This depression is well recorded in all regions (BGZ I to III, TVZ; Figures 2 and 5) by the AW, RSD and the RC curves. However, it is important to remember that these records only have a 200 year resolution. The SPD curves suggest a much shorter-lived dip of 
around a century, in keeping with the arguments of Schneider et al. (2007) that the early Medieval period was a dynamic one, with the exception of a century of abandonment from $c$. 1300-1200 BP. This likely population decline associated with regional population restructuring, albeit probably short-lived, is reflected in pollen records, mainly in BGZ I and III, where API, RHAPI and LPI indicators strongly decrease while AP sum clearly marks a reforestation phase in BGZ I (Figure 9b), lasting a century in the pollen record from Palavas(e.g. Azuara et al., 2015). The dynamics of pollen assemblages are clearly different in BGZ II, where the AP sum continue to decrease, associated with a clear maximum in API and RHAPI indicators. A reorganisation of the settlements during the early Medieval period towards the plateaus and hills and the middle mountain could explain these signatures (Argant and Cubizolles, 2005; Berger, 2015; Doyen et al., 2013; Schneider, 2004, Schneider et al., 2007).

\section{Threshold 7: 1000 cal. yr BP and later}

From the 10th century, that is shortly before 1000 cal. yr BP, there was a new momentum marked by an increase in the number of sites. In the BGZ III region, the growth in the number of sites is relatively short since it falls shortly after $1000 \mathrm{BP}$, around the 12 th century $\mathrm{CE}$. In the other two regions, this decline is not visible, although it is well recorded in the Archaeomedes microregional curves for the most coastal areas (Favory et al., 1999). Only the curves of the micro-regions north of BGZI or at the BGZII interface show the same signal with continuous growth. Despite a much smaller number of sites at this time than around 1950-1850 BP, micro-regional studies demonstrate that the overall area occupied by the sites is comparatively almost at the same level (Favory et al., 1999). In Languedoc, the typological analysis of the sites also shows for this period a replacement of the small and medium size occupations by larger and potentially more long-lasting ones. Therefore, as the trajectory for the cumulative occupied area shows (Figure 6b), the observed decrease in the number of sites compared with previous periods, especially antiquity, is not a sign of a demographic decline. In fact, it marks the affirmation of the medieval hierarchy and networks underpinned by a much more regular territorial meshwork (Archaeomedes, 1998).

During this period and for BGZ1, the local pastoral indicators and the anthropological index (API) are at their highest level, while the OJC index increases strongly. This signal is perfectly consistent with the idea of a settlement reorganisation and the consolidation of the agrarian exploitation around certain places that are more regularly dispersed (Fovet, 2004. As observed by Durand and Leveau (2004), 'The growth in farming in the 8th-9th $\mathrm{C}$, resting on a demographic increase combined with intensive land clearance episodes, owes much to the preceding centuries: the change resides more in the intensification than in the introduction of new features'.

\section{Conclusion}

This paper has traced the various trajectories of population and vegetation change in Mediterranean southern France over the course of the Holocene by comparing and contrasting a range of different proxies. Earlier microregional survey and excavation projects have made it possible to assess and confirm the relative representativeness of the radiocarbon SPD and site-count data for the region as a whole and generally support the broader regional patterns (though it has not been possible to include site-size data). The results indicate a pattern of population fluctuations, revealed in greater detail in the SPD proxy but also evident in the sitecount data for the TVZ dataset, for which it was possible to create and apply finer typo-chronological subdivisions.
There is a strong correlation between the population proxies and the various land cover indicators of human impact. This includes the SPD proxy, even though the correlations for this are based only on the period up to $2400 \mathrm{cal}$. yr BP, but the values are generally lower than for the transformed site count-data (AW and RSD), confirming the greater human impact in the later periods that is clearly seen in Figure 9.

In contrast to many other Mediterranean regions, data on climate fluctuations independent of the land-cover proxies presented in this paper are currently lacking for southern France. Consequently, at present we are not in a position to assess climatic impacts on the changing vegetation patterns or on the size of the human population through an effect on the agricultural resources that sustained them, from evidence available within the study region. On the other hand, it is clear that at least from $2500 \mathrm{cal}$. yr BP we cannot explain patterns of population and land cover in purely local terms. They result from the incorporation of southern France into much larger Mediterranean-wide trade systems and the restructuring of the landscape that this involved.

\section{Acknowledgements}

Pollen data were extracted from the European Pollen Database (EPD; http://www.europeanpollendatabase.net/) and amalgamated from the work of data contributors. The EPD community is gratefully acknowledged and gratitude is given to Michelle Leydet (the EPD manager), and many data contributors who have made a valuable contribution to this research. The authors also thank A Beeching, JL Brochier and F Ferber for their communication of unpublished radiocarbon series from the Chassean period and $\mathrm{C}$ Baudouin for her pollen database of the Rhone delta. Finally, the authors are grateful to Joan Estrany and the University of the Balearic Islands for hosting the Mallorca workshop.

\section{Funding}

This work is the result of a workshop held in Mallorca in September 2017 under the umbrella of the Leverhulme Trust funded project 'Changing the Face of the Mediterranean: Land Cover and Population Since the Advent of Farming' (Grant no.: RPG-2015031), a Plymouth-UCL collaboration.

\section{ORCID iDs}

Alessio Palmisano (D) https://orcid.org/0000-0003-0758-5032

Julien Azuara (iD) https://orcid.org/0000-0002-3533-3281

Andrew Bevan (iD) https://orcid.org/0000-0001-7967-3117

Ralph Fyfe (iD) https://orcid.org/0000-0002-5676-008X

\section{References}

Andrieu-Ponel V, Ponel P, Bruneton H et al. (2000a) Palaeoenvironments and cultural landscape of the last 2000 years reconstructed from pollen and coleopteran records in the lower Rhône valley, southern France. The Holocene 10: 341-355.

Andrieu-Ponel V, Ponel P, Jull AJT et al. (2000b) Towards the reconstruction of the Holocene vegetation history of Lower Provence: Two new pollen profiles from Marais des Baux. Vegetation History and Archaeobotany 9: 71-85.

Archaeomedes (1998) The Archaeomedes Project: Understanding the Natural and Anthropogenic Causes of Land Degradation and Desertification in the Mediterranean Basin. Brussels: European Commission.

Argant J (1990) Climat et environnement au Quaternaire dans le bassin du Rhône d'après les données palynologiques. Documents du Laboratoire de Géologie de Lyon 3: 1-199.

Argant J (2010) Pollen profile CZE1, Marais de Charauze, France. European Pollen Database (EPD), PANGAEA. Available at: https://doi.org/10.1594/PANGAEA.738766. 
Argant J and Argant A (2000) Mise en évidence de l'occupation ancienne d'un site d'altitude: analyse pollinique du lac du Lauzon (Drôme). Géologie Alpine 31: 61-71.

Argant $\mathrm{J}$ and Cubizolles H (2005) L'évolution holocène de la végétation des Monts de la Madeleine, du Forez, du Livradois et du Pilat (Massif Central oriental, France): l'apport d'une nouvelle série d'analyses palynologiques. Quaternaire. Revue de l'Association Française pour l'Etude du Quaternaire 16: 119-142.

Argant J, Heinz C and Brochier J (1991) Pollens, charbons de bois et sédiments: l'action humaine et la végétation, le cas de la grotte d'Antonnaire (Montmaur-en-Diois, Drôme). Revue D'archéométrie 15: 29-40.

Arnaud F, Revel-Rolland M, Chapron E et al. (2005) 7200 years of Rhône river flooding activity recorded in Lake Le Bourget: A high resolution sediment record of NW Alps hydrology. Holocene 15: 420-428.

Arnaud F, Wessels M, Chapron E et al. (2008) Signaux terrigènes dans les grands lacs subalpins: un marqueur régional à haute résolution des conditions paléohydrologiques? In: Magny $\mathrm{M}$, Desmet $\mathrm{M}$ and Mocci F (eds) GDR JURALP, Nov 2007. Aixen-Provence: Collection EDYTEM - Cahiers de Paléoenvironnement 6, pp. 77-88.

Azuara J, Combourieu-Nebout N, Lebreton V et al. (2015) Late Holocene vegetation changes in relation with climate fluctuations and human activity in Languedoc (southern France). Climate of the past 11: 1769-1784.

Azuara J, Lebreton V, Peyron O et al. (2018) The Holocene history of low altitude Mediterranean Fagus sylvatica forests in southern France. Journal of Vegetation Science 29: 438-449.

Bailly-Maitre MC and Gonon T (2008) L'exploitation de la chalcopyrite à l'âge du Bronze dans le massif des Rousses en Oisans (Isère): premiers éléments. Paris: Editions du CTHS.

Beeching A (1991) Sépultures, territoire et société dans le Chasséen méridional. L'exemple du basin rhodanien. In: Identité $d u$ Chasséen, Actes du Colloque international de Nemours, 1989. Mémoires du Musée de Préhistoire d'Ile-de 4. Nemours: Editions A.P.R.A.I.F., pp. 327-341.

Beeching A (2002) La fin du Chasséen et le Néolithique final dans le bassin du Rhône moyen. In: Ferrari A and Visentini $\mathrm{P}$ (eds) Il declino del mondo neolitico. Ricerche in Italia centro-settentrionale fra aspetti peninsulari, occidentali e nordalpini, Atti del Convegno di Pordenone, 5-7 Aprile 2001. Pordenone: Museo delle Scienze, pp. 67-83.

Beeching A, Berger JF, Brochier JL et al. (2000) Chasséens: agriculteurs ou éleveurs, sédentaires ou nomades? Quels types de milieux, d'économies et de sociétés? Sociétés et Espaces. Toulous: Archives d'Ecologie Préhistorique, pp. 59-76.

Berger JF (2011) Hydrological and post-depositional impacts on the distribution of Holocene archaeological sites: The case of the Holocene middle Rhône River basin, France. Geomorphology 129: 167-182.

Berger JF (2015) Approche socio-environnementale du Néolithique à l'Anthropocène: quelques études intégrées de la vallée du Rhône aux milieux nord Méditerranéens. Habilitation à Diriger des Recherches, Spécialité: Géographie physique, Université Lyon, 2.

Berger JF and Bravard JP (2012) Le développement économique romain face aux crises environnementales. Le cas de la Gaule Narbonnaise. In: Berger JF (ed.) Colloque international: "Des climats et des Hommes: glaciologie, climatologie, archéologie, histoire », Paris, Cité de la Science, 17-19 nov. 2009. Paris: éditions la Découverte, pp. 269-289.

Berger JF, Brochier JL, Vital J et al. (2007) Nouveau regard sur la dynamique des paysages et l'occupation humaine à l'Âge du Bronze en moyenne vallée du Rhône. Environnements et
Cultures à L'âge du Bronze en Europe Occidentale, Éditions du CTHS (Documents Préhistoriques) 21: 259-284.

Berger JF, Delhon C, Magnin F et al. (2016) A fluvial record of the mid-Holocene rapid climatic changes in the middle Rhone valley (Espeluche-Lalo, France) and of their impact on Late Mesolithic and Early Neolithic societies. Quaternary Science Reviews 136: 66-84.

Berger JF, Magnin F, Thiébault S et al. (2000) Emprise et déprise culturelle à l'Age du Bronze: l'exemple du Bassin Valdainais (Drôme) et de la moyenne vallée du Rhône. Bulletin de la Société Préhistorique Française 97: 95-119.

Berger JF, Nuninger L and Van Der Leeuw S (2007) Modeling the role of resilience in socio-environmental co-evolution: The middle Rhone valley between $1000 \mathrm{BC}$ and $\mathrm{AD} 1000$. In: Kolher T and Van der Leeuw SE (eds) Modeling Socioecological Systems. Santa Fe, NM: SAR Press, pp. 41-59.

Bernigaud N, Berger JF, Bouby L et al. (2014) Ancient canals in the valley of Bourgoin-La Verpillière (France, Isère): Morphological and geoarchaeological studies of irrigation systems from the Iron Age to the Early Middle Ages (8th century bc-6th century ad). Water History 6: 73-93.

Bertoncello F, Fovet E, Gandini C et al. (2012) Spatio-temporal dynamics of settlement patterns in central and southern Gaul from $800 \mathrm{BC}$ to $800 \mathrm{AD}$ : Models for long-term interregional comparison. In: Gandini C, Favory F and Nuninger L (eds) Settlement Patterns, Production end Trades from the Neolithic to the Middle Ages. ARCHAEDYN, Seven Millennia of Territorial Dynamics, Final Conference, Dijon, 23-25 June 2008. Oxford: Archaeopress, pp. 51-64.

Bevan A, Colledge S, Fuller D et al. (2017) Holocene fluctuations in human population demonstrate repeated links to food production and climate. Proceedings of the National Academy of Sciences 114: E10524-E10531.

Billaud Y (1999) Laprade, Lamotte-du-Rhône (Vaucluse): un habitat de plaine à architecture de terre au Bronze final $2 \mathrm{~b}$. Bulletin de la Société Préhistorique Française 96: 607-621.

Blaauw M and Christen JA (2011) Flexible paleoclimate agedepth models using an autoregressive gamma process. Bayesian Analysis 6: 457-474.

Blanchemanche P (2006) Unpublished interim report of the ARMILIT project to the French National Research Agency.

Bossuet G, Ruffaldi P, Magny M et al. (1996) Dynamique et approche quantitative des remplissages fini- et postwuermiens du bassin lacustre de Cerin (Jura, France). Bulletin de la Société géologique de France 167: 483-493.

Bouby L (2010) Agriculture dans le bassin du Rhône du Bronze final à l'Antiquité: agrobiodiversité, économie, cultures. Doctoral dissertation, EHESS.

Bravard JP, Vérot-Bourrely A, Franc O et al. (1997) Paléodynamique du site fluvial de Lyon depuis le Tardiglaciaire. Documents d'Archéologie en Rhône-Alpes 15: 177-201.

Bréhard S, Beeching A and Vigne JD (2010) Shepherds, cowherds and site function on middle Neolithic sites of the Rhône valley: An archaeozoological approach to the organization of territories and societies. Journal of Anthropological Archaeology 29: 179-188.

Brochier JL, Beeching A, Sidi Maamar H et al. (1999) Les grottes bergeries des Préalpes et le pastoralisme alpin, durant la fin de la Préhistoire. In: Beeching A (ed.) Circulations et identités culturelles alpines à la fin de la préhistoire. Valence: Centre d'Archéologie préhistorique de Valence, Travaux du Centre d'Archéologie préhistorique de Valence no. 2, pp. 77-114.

Brochier JL, Borel JL and Druart JC (2007) Les variations paléoenvironnementales de 1000 avant à 1000 après $\mathrm{JC}$ et la question des «optima» climatiques de l'Antiquité tardive et du Moyen Âge sur le piémont des Alpes du nord à Colletière, 
lac de Paladru, France. Quaternaire. Revue de l'Association Française pour l'Etude du Quaternaire 18: 253-270.

Brun J-P and Congès G (1996) Une crise agraire en Provence au troisième siècle ? In: Fiches JL (ed.) Le IIIe siècle en Gaule narbonnaise. Antibes: APDCA, pp. 233-276.

Carozza L, Berger JF, Burens-Carozza A et al. (2015) Society and environment in Southern France from the 3rd millennium BC to the beginning of the 2nd millennium BC: $2200 \mathrm{BC}$ a tipping point? In: Meller H (ed.) 2200BC - A Climatic Breakdown as a Cause for the Collapse of the Old World?, vol. 12. Halle: Tagungen des Landesmuseum für vorgeschichte, pp. 333-362.

Carozza L, Georjon C and Vignau A (2005) La Fin du Néolithique et les debuts de la métallurgie en Languedoc central. Les habitats de la colline du Puech Haut à Paulhan, Hérault. Toulouse: Archives d'écologie préhistorique.

Cartier R, Brisset E, Paillès C et al. (2015) 5000 years of lacustrine ecosystem changes from Lake Petit (Southern Alps, $2200 \mathrm{~m}$ asl): Regime shift and resilience of algal communities. The Holocene 25: 1231-1245.

Clerc J (1988) Recherches pollenanalytiques sur la paléo-écologie Tardiglaciaire et Holocène du Bas-Dauphiné. PhD Dissertation, Université St. Jérôme.

Clerc J (2010) Pollen profile LORAS84, Loras, France. European Pollen Database (EPD), PANGAEA. Available at: https://doi. org/10.1594/PANGAEA.739484

Collectif (2002a) Archéologie du TGV Méditerranée. Fiches de Synthèse. Tome 1. La Préhistoire (Monographies d'Archéologie Méditerranéenne (MAM) 8). Lattes: Association pour la Recherche Archéologique en Languedoc Oriental.

Collectif (2002b) Archéologie du TGV Méditerranée. Fiches de Synthèse. Tome 2. La Protohistoire (Monographies d'Archéologie Méditerranéenne (MAM), 9). Lattes: Association pour la Recherche Archéologique en Languedoc Oriental.

Collectif (2002c) Archéologie du TGV Méditerranée. Fiches de Synthèse. Tome 3. Antiquité, Moyen-âge, Époque Moderne (Monographies d'Archéologie Méditerranéenne (MAM), 10). Lattes: Association pour la Recherche Archéologique en Languedoc Oriental.

Crema ER (2012) Modelling temporal uncertainty in archaeological analysis. Journal of Archaeological Method and Theory 19: $440-461$.

Crema ER and Bevan A (2018) rcarbon v1.1.2: Methods for calibrating and analysing radiocarbon dates. Available at: https:// CRAN.R-project.org/package $=$ rcarbon.

Crema ER, Bevan A and Lake M (2010) A probabilistic framework for assessing spatio-temporal point patterns in the archaeological record. Journal of Archaeological Science 37: $1118-1130$.

Crema ER, Habu J, Kobayashi K et al. (2016) Summed probability distribution of $14 \mathrm{C}$ dates suggests regional divergences in the population dynamics of the Jomon Period in Eastern Japan. PLOS ONE 11: e0154809.

Davis BA, Zanon M, Collins P et al. (2013) The European modern pollen database (EMPD) project. Vegetation History and Archaeobotany 22: 521-530.

Davis BAS, Brewer S, Stevenson AC et al. (2003) The temperature of Europe during the Holocene reconstructed from pollen data. Quaternary Science Reviews 22: 1701-1716.

de Beaulieu JL (1974) Evolution de la végétation sur la bordure montagneuse cévenole au Postglaciaire d'après les pollens. Bulletin de la Société Languedocienne de Géographie 8: 347-358.

de Beaulieu JL (1977) Contribution pollenanalytique à l'histoire tardiglaciaire et Holocène de la végétation des Alpes méridionales françaices. PhD Dissertation, Université d'Aix-Marseille. de Beaulieu JL (2010) Pollen profile SABBION1, Sabbion, France. European Pollen Database (EPD), PANGAEA. Available at: https://doi.org/10.1594/PANGAEA.739772.

de Beaulieu JL, Clerc J, Couteaux M et al. (1982) Pollenanalyses and characters of climatic changes at the end of the Eemian and at the beginning of the Late Wurm in Western Europe. In: Ghazi A (ed.) Palaeoclimatic Research and Models: Report and Proceedings of the Workshop held in Brussels. Dordrecht: Springer, pp. 108-113.

de Beaulieu JL, Miras Y, Andrieu-Ponel V et al. (2005) Vegetation dynamics in north-western Mediterranean regions: Instability of the Mediterranean bioclimate. Plant Biosystems 139: $114-126$.

Delhon C and Thiébault S (2008) An approach to Holocene vegetation history in the middle Rhone valley (France): Anthracological data from the «TGV-Méditerranée» excavations. In: Fiorentino $\mathrm{G}$ and Magri D (eds.) Charcoal from the past, Cultural and palaeoenvironmental implications. Proceedings of the Third International Meeting of Anthracology, CavallinoLecce (Italy), June 28th- July 1st 2004. Oxford: Archaeopress, pp. 63-73.

Delhon C, Thiébault S and Berger JF (2009) La gestion de l'environnement et du paysage au Moyen Néolithique dans le sud de la France: des preuves de systèmes agro-sylvo-pastoraux dans la vallée du Rhône moyen. Quaternaire International 200: 50-65.

Denaire A, Doppler T, Nicod PY et al. (2011) Espaces culturels, frontières et interactions au 5 ème millénaire entre la plaine du Rhin supérieur et les rivages de la Méditerranée. Annuaire d'Archéologie Suisse 94: 21-59.

Digerfeldt G, de Beaulieu JL, Guiot J et al. (1997) Reconstruction and paleoclimatic interpretation of Holocene lake-level changes in Lac de Saint-Léger, Haute-Provence, southeast France. Palaeogeography, Palaeoclimatology, Palaeoecology 136: 231-258.

Doyen É, Bégeot C, Simonneau A et al. (2016) Land use development and environmental responses since the Neolithic around Lake Paladru in the French Pre-alps. Journal of Archaeological Science: Reports 7: 48-59.

Doyen É, Vannière B, Berger JF et al. (2013) Land-use changes and environmental dynamics in the upper Rhone valley since Neolithic times inferred from sediments in Lac Moras. The Holocene 23: 961-973.

Drysdale R, Zanchetta G, Hellstrom J et al. (2006) Late Holocene drought responsible for the collapse of Old World civilizations is recorded in an Italian cave flowstone. Geology 34: $101-104$.

Durand A and Leveau P (2004) Farming in Mediterranean France and rural settlement in the Late Roman and Early Medieval periods: The contribution from archaeology and environmental sciences in the last twenty years. In: Barcelo $\mathrm{M}$ and Sigaut F (eds) The Making of Feudal Agricultures. Leiden: Brill, pp. 177-253.

Eicher U, Siegenthaler U and Wegmüller S (1981) Pollen and oxygen isotope analyses on Late- and Post-glacial sediments of the tourbière de Chirens (Dauphiné, France). Quaternary Research 15: 160-170.

Favory F and Fiches JL (1994) Les Campagnes de la France méditerranéenne dans l'Antiquité et le haut Moyen Âge: études microrégionales. Paris: Editions de la Maison des sciences de l'homme.

Favory F, Girardot JJ, Nuninger L et al. (1999) ARCHAEOMEDES II: une étude de la dynamique de l'habitat rural en France méridionale, dans la longue durée (800 av. J.-C.-1600 ap. J.-C.). AGER 9: 15-35.

Favory F, Nuninger L and Sanders L (2012) Integration of geographical and spatial archeological concepts for the study of 
settlement systems. Espace Géographique (English Edition) 41: 272-287.

Favory F, Ouriachi MJ and Nuninger L (2011) The transformation of rural structures in Southern Gaul between the first century $\mathrm{BC}$ and the first century AD. The case of eastern Languedoc (France). In: Moosbauer G and Wiegels R (eds) Fines imperii - imperium sine fine? Römische Okkupations- und Grenzpolitik im frühen Prinzipat. Rahden: VML, pp. 157-184.

Finné M, Woodbridge J, Labuhn I et al. (IN PRESS) Holocene hydro-climatic variability in the Mediterranean: a synthetic multi-proxy reconstruction. The Holocene 29(5). DOI: $10.1177 / 0959683619826634$

Fovet E (2004) Dynamique spatiale du peuplement et analyse des ressources agro-pastorales dans le bassin de Combas et le vallon de l'Aigalade (Gard, France), du Bronze final au bas Moyen Age. In: Berger J-F, Bertoncello F, Braemer F et al. (eds) Temps et espaces de l'Homme en société, analyses et modèles spatiaux en archéologie. Antibes: éditions APDCA, pp. 499-503.

Fyfe RM, de Beaulieu J-L, Binney H et al. (2009) The European Pollen Database: Past efforts and current activities. Vegetation History and Archaeobotany 18: 417-424.

Fyfe RM, Woodbridge J and Roberts CN (2018) Trajectories of change in Mediterranean Holocene vegetation through classification of pollen data. Vegetation History and Archaeobotany 27: 351-364.

Gandini C, Favory F and Nuninger L (2012) Settlement Patterns, Production and Trades from the Neolithic to the Middle Ages. Oxford: Archaeopress.

Garcia D and Isoardi D (2010) Variations démographiques et capacités de production des céréales dans le Midi Gaulois: l'impact de Marseille grecque. In: Tréziny H (ed.) Grecs et indigènes de la Catalogne à la mer noire, vol. 3. Aix-enProvence: Bibliothèque d'archéologie méditerranéenne et africaine, Centre Camille Jullian, pp. 403-424.

Giesecke T, Davis BAS, Brewer S et al. (2013) Towards mapping the late Quaternary vegetation change of Europe. Vegetation History and Archaeobotany 23: 75-86.

Guilaine J and Manen C (2005) From Mesolithic to early Neolithic in the western Mediterranean. In: Whittle A and Cummings V (eds) Going over: The Mesolithic-Neolithic Transition in the North-West Europe. Oxford: Oxford University Press, pp. 21-51.

Guillon S (2007) L'étang de Montady (Hérault), une séquence lacustro-palustre témoin de l'histoire environnementale et agraire languedocienne. Discussion autour de la transition Subboréal/ Subatlantique. In: Abbé JL (dir) Autour de l'étang de Montady. Espace, environnement et mise en valeur du milieu humide en Languedoc, des oppida à nos jours. Unpublished PCR report, pp. 43-47.

Guillon S (2014) Dynamique de la végétation alluviale côtière dans le Sud-Est de la France. PhD Thesis, University of Nice.

Guiot J and Kaniewski D (2015) The Mediterranean Basin and Southern Europe in a warmer world: What can we learn from the past? Frontiers in Earth Science 3: 28.

Guiter F, Andrieu-Ponel V, Digerfeldt G et al. (2005) Vegetation history and lake-level changes from the Younger Dryas to the present in Eastern Pyrenees (France): pollen, plant macrofossils and lithostratigraphy from Lake Racou (2000 m a.s.1.). Vegetation History and Archaeobotany 14: 99-118.

Gutherz X and Jallot L (1999) Approche géoculturelle des pays fontbuxiens. In: Vaquer J (ed.) Le Néolithique du Nord-Ouest méditerranéen, Actes du XXIVe Congrès Préhistorique de France, colloque 2, Carcassonne, 1994. Paris: Éditions Société Préhistorique Française, pp. 161-174.
Gutherz X and Odiot T (2001) L'archéologie du TGV-Méditerranée: retour sur une expérience. Les Nouvelles de l'Archéologie 86(4): 17-21.

Jalali B, Sicre MA, Bassetti MA et al. (2016) Holocene climate variability in the North-Western Mediterranean Sea (Gulf of Lions). Climate of the Past 12: 91-101.

Jalali B, Sicre M-A, Kallel N et al. (2017) High-resolution Holocene climate and hydrological variability from two major Mediterranean deltas (Nile and Rhone). The Holocene 27(8): $1158-1168$.

Jalut G, Amat AE, Bonnet L et al. (2000) Holocene climatic changes in the Western Mediterranean, from south-east France to south-east Spain. Palaeogeography, Palaeoclimatology, Palaeoecology 160: 255-290.

Jalut G, Dedoubat JJ, Fontugne M et al. (2009) Holocene circum-Mediterranean vegetation changes: Climate forcing and human impact. Quaternary International 200: 4-18.

Juggins S (2015) Rioja': Analysis of Quaternary Science Data, R package version (0.9-9). Available at: http://cran.r-project. org/package $=$ rioja.

Lachenal T (2012) L'age du bronze en Provence: productions ceramiques et dynamiques culturelles. Doctoral dissertation, Atelier national de reproduction des thèses.

Lemercier O (2007) La fin du Néolithique dans le sud-est de la France. Concepts techniques, culturels et chronologiques de 1954 à 2004. Un siècle de construction du discours scientifique en Préhistoire. In: Actes du XXVIe Congrès Préhistorique de France, 21-25 Septembre 2004, Avignon 1. Paris: BSPF, pp. 484-500.

Lemercier O, Furestier R, Gadbois-Langevin R et al. (2014) Chronologie et périodisation des campaniformes en France méditerranéenne. In: Sénépart I, Leandri F, Cauliez J et al. (eds) Chronologie de la Préhistoire récente dans le Sud de la France. Acquis 1992-2012. Actualité de la recherche. Actes des 10e Rencontres Méridionales de Préhistoire Récente, Porticcio, 18 au 20 octobre 2012. Toulouse: Archives d'Ecologie Préhistorique, pp. 175-195.

Leveau P (1998) Echelles d'anthropisation et archéologie des campagnes de Gaule du Sud à l'époque romaine. Méditerranée 90(4): 17-26.

Leveau P (2007) Archéologie et géoarchéologie d'une période historique dans les Alpes: les paradigmes épistémologiques de la romanisation. Géomorphologie: Relief, Processus, Environnement 13: 85-98.

Loison G, Gandelin M, Vergély H et al. (2011) Dynamiques d'occupation des sols à la Préhistoire récente dans la basse vallée de l'Hérault: les apports de l'A75, tronçon PézenasBéziers. In: Marges, frontières et transgressions: actualité de la recherche, actes des 8es Rencontres méridionales de Préhistoire récente, Marseille, 7-8 November 2008. Toulouse: Archives d'écologie préhistorique, pp. 317-344.

McDermott F, Frisia S, Huang Y et al. (1999) Holocene climate variability in Europe: Evidence from $\delta 180$, textural and extension-rate variations in three speleothems. Quaternary Science Reviews 18: 1021-1038.

Magny M, Bossuet G, Ruffaldi P et al. (2011) Orbital imprint on Holocene palaeohydrological variations in west-central Europe as reflected by lake-level changes at Cerin (Jura Mountains, eastern France). Journal of Quaternary Science 26: $171-177$.

Magny M, Peyron O, Gauthier E et al. (2009) Quantitative reconstruction of climatic variations during the Bronze and early Iron ages based on pollen and lake-level data in the NW Alps, France. Quaternary International 200: 102-110.

Marguet A, Bintz P, Nicod PY et al. (2008) Eléments pour une histoire du peuplement nord-alpin français entre 10000 et 2700 BP. In: Desmet M (ed.) GDR JURALP Collection EDY- 
TEM-Cahiers de Paléoenvironnement 6. Le Bourget-du-Lac: Université de Savoie, pp. 225-252.

Martin S and Magnin F (2002) Caractérisation des perturbations anthropiques dans la séquence holocène de l'Ubac (Goult, Vaucluse), à partir de la malacofaune. Annales Litterairesuniversite de Besancon, Dialogues d'Histoire Ancienne 730: 205-212.

Mazier F, Galop D, Brun C et al. (2006) Modern pollen assemblages from grazedvegetation in the western Pyrenees, France: A numerical tool for more precise reconstruction of past cultural landscapes. The Holocene 16: 91-103.

Mazier F, Galop D, Gaillard MJ et al. (2009) Multidisciplinary approach to reconstructing local pastoral activities: An example from the Pyrenean Mountains (Pays Basque). The Holocene 19: 171-188.

Mercuri AM, Bandini Mazzanti M, Florenzano A et al. (2013a) Olea, Juglans and Castanea: The OJC group as pollen evidence of the development of human-induced environments in the Italian peninsula. Quaternary International 303: 24-42.

Mercuri AM, Mazzanti M, Florenzano A et al. (2013b) Anthropogenic pollen indicators (API) from archaeological sites as local evidence of human-induced environments in the Italian peninsula. Annali di Botanica 3: 143-153.

Nakagawa T (1998) Pollen studies in the central meridional French Alps: Lateglacial and Holocene vegetation history. PhD Dissertation, University of Marseille III.

Nicol-Pichard S and Dubar m (1998) Reconstruction of late-glacial and holocene environments in southeast France based on the study of a 66-m long core from Biot, Alpes Maritimes. Vegetation History and Archaeobotany 7: 11-15.

Notebaert B and Berger JF (2014) Quantifying the anthropogenic forcing on soil erosion during the Iron Age and Roman Period in southeastern France. Anthropocene 8: 59-69.

Nuninger L, Verhagen P, Tourneux FP et al. (2012) Contextes spatiaux et transformation du systeme de peuplement: approche comparative et predictive. In: Bertoncello $\mathrm{F}$ and Braemer $\mathrm{F}$ (eds) Variabilités environnementales, mutations sociales. Nature, intensités, échelles et temporalités des changements. Antibes: APDCA, pp. 139-154.

Palmisano A, Bevan A and Shennan S (2017) Comparing archaeological proxies for long-term population patterns: An example from central Italy. Journal of Archaeological Science 87: 59-72.

Perez M, Fyfe RM, Charman DJ et al. (2015) Later Holocene vegetation history of the Isles of Scilly, UK: Coastal influence and human land use in a small island context. Journal of Quaternary Science 30: 764-778.

Perrin T, Manen C, Séjalon P et al. (2014) Le Néolithique Ancien De La Plaine De Nimes (Gard, France). Toulouse: Archives d'écologie préhistorique.

Pétrequin P and Weller O (2007) XVe siècle av. J.-C.: la reprise de la croissance démographique dans le Jura. In: Richard H, Magny $\mathrm{M}$ and Mordant $\mathrm{C}$ (eds) Emprises, déprises et rythmes agricoles à l'Age du Bronze. Actes du Colloque CTHS Besançon 2004, vol. 21. Paris: Documents préhistoriques du CTHS, pp. 197-210.

Peyron O, Combourieu-Nebout N, Brayshaw D et al. (2017) The climate of the Mediterranean basin during the Holocene from terrestrial and marine pollen data: A model/data comparison. Climate of the Past 13: 249-265.

Pons A and Quézel P (1998) A propos de la mise en place du climat méditerranéen. Comptes Rendus de l'Académie des Sciences-Series IIA-Earth and Planetary Science 327: 755-760.

Puertas O (1997) Evolution de la végétation depuis le Dryas récent dans la plaine littorale de Montpellier (Hérault, France) à partir de l'analyse pollinique. Dynamique naturelle et anthropisation du milieu. $\mathrm{PhD}$ Dissertation, Université de Franche-Comté.

Puertas O (1999) Premiers indices polliniques de néolithisation dans la plaine littorale de Montpellier (Hérault, France). Bulletin de la Société préhistorique française 96: 15-20.

Pulido M (2006) Anthropogenic impact on the postglacial vegetation dynamics in South Massif Central, France. Thesis of Palaeoecology, University of Marseille III.

Raynaud C (2003) Les systèmes agraires antiques: quelle approche archéologique? In: Lepetz S and Matterne V (eds) Cultivateurs, éleveurs et artisans dans les campagnes de Gaule romaine, $\mathrm{n}^{\circ} 12$. Senlis: Revue archéologique de Picardie, pp. 281-298.

Reimer PJ, Bard E, Bayliss A et al. (2013) IntCal13 and Marine13 radiocarbon age calibration curves $0-50,000$ Years cal BP. Radiocarbon 55: 1869-1887.

Richard H (2004) Néolithisation précoce: premières traces d'anthropisation du couvert végétal à partir des données polliniques. Besancon: Presses Universitaires de Franche-Comté.

Richard H and Gauthier E (2007) Bilan des données polliniques concernant l'âge du Bronze dans le Jura et le nord des Alpes. Environnements et Cultures à l'Âge du Bronze en Europe Occidentale, Paris, Éditions. Du CTHS (Documents Préhistoriques) 21: 71-88.

Roberts N, Brayshaw D, Kuzucuoğlu C et al. (2011) The midHolocene climatic transition in the Mediterranean: Causes and consequences. The Holocene 21: 3-13.

Roberts N, Woodbridge J, Bevan A et al. (2018) Human responses and non-responses to climatic variations during the last glacial-interglacial transition in the eastern Mediterranean. Quaternary Science Reviews 184: 47-67.

Sanchez-Goñi MF (1995) In: Guilaine J (ed.) Temps et espace da ns le bassin de l'Aude du Neolithique a l'Age du Fer. Toulouse: CNRS, pp. 265-275.

Schneider L (2004) Entre Antiquité et haut Moyen Age: tradition et renouveau de l'habitat de hauteur dans la Gaule du sud-est. In: Paul-Albert Février de l'Antiquité au Moyen Age, Actes du colloque de Fréjus, 7 et 8 avril 2001. Aix-en-Provence: Publications de l'Université de Provence, pp. 173-200.

Schneider L, Fauduet I and Odenhardt-Donvez I (2007) Structures du peuplement et formes de l'habitat dans les campagnes du sud-est de la France de l'Antiquité au Moyen Âge (IVe-VIIIes.): essai de synthèse. Gallia 64: 11-56.

Shennan S, Downey SS, Timpson A et al. (2013) Regional population collapse followed initial agriculture booms in midHolocene Europe. Nature Communications 4: 2486.

Simonneau A, Doyen E, Chapron E et al. (2013) Holocene land-use evolution and associated soil erosion in the French Prealps inferred from Lake Paladru sediments and archaeological evidences. Journal of Archaeological Sciences 40: $1636-1645$

Thiébault S (2005) L'apport du fourrage d'arbre dans l'élevage depuis le Néolithique. Anthropozoologica 40: 95-108.

Timpson A, Colledge S, Crema E et al. (2014) Reconstructing regional population fluctuations in the European Neolithic using radiocarbon dates: A new case-study using an improved method. Journal of Archaeological Science 52: 549-557.

Treffort JM (2005) La fréquentation des cavités naturelles du Jura méridional au Bronze final: état de la question, nouvelles données et perspectives. Bulletin de la Société Préhistorique Française 102: 401-416.

Van der Leeuw SE (2001) Vulnerability' and the integrated study of socio - natural phenomena. Bonn: IHDP Update, 2/01, 6-7 April.

Van der Leeuw SE Archaeomedes Research Team (2005) Climate, hydrology, land use, and environmental degradation in 
the lower Rhone Valley during the Roman period. Comptes Rendus Geoscience 337: 9-27.

Van der Leeuw SE, Favory F, Fiches JL et al. (2003) Archéologie et systèmes socio-environnementaux: études multiscalaires sur la vallée du Rhône dans le programme Archaeomedes. Antibes: CNRS.

Vella C and Provansal M (2000) Relative sea-level rise and neotectonic events during the last $6500 \mathrm{yr}$ on the southern eastern Rhône delta, France. Marine Geology 170: 27-39.

Verhagen P and Berger JF (2001) Predictive modelling of buried archaeological sites in the Tricastin-Valdaine Region (Middle Rhone Valley, France). In: Stancic Z and Veljanovic T (eds) CAA 2000: Computing Archaeology for Understanding the past, Joint CAA/UISPP Commission IV Conference. Oxford: BAR International Series, pp. 219-231.

Vernet JL and Thiébault S (1987) An approach to northwestern Mediterranean recent prehistoric vegetation and ecologic implications. Journal of Biogeography 14: 117-127.

Vital J (1990) Protohistoire du défilé de Donzère: l'âge du bronze dans la Baume des Anges (Drôme). Paris: Editions de la Maison des Sciences de l'homme.

Vital J (2012) Repères chronométriques, typologiques et géographiques pour la céramique du Bronze final du Rhône aux Alpes. Documents d'Archéologie Méridionale. Protohistoire du Sud de la France 35: 53-84.
Vital J (2014) La chronologie céramique du Bronze ancien et moyen du Massif central aux Alpes. In Senepart I, Leandri F, Cauliez J et al. (eds) Chronologie de la Préhistoire récente dans le Sud de la France. Acquis 1992-2012. Actualité de la recherche. Actes des 10e Rencontres Méridionales de Préhistoire Récente, Porticcio, 18 au 20 octobre 2012. Toulouse: Archives d'Écologie Préhistorique, pp. 221-238.

Walsh K, Berger J-F, Neil Roberts C et al. (IN PRESS) Holocene demographic fluctuations, climate and erosion in the Mediterranean: A meta data-analysis. The Holocene 29(5). DOI:10.1177/0959683619826637

Walsh K, Richer S and de Beaulieu JL (2006) Attitudes to altitude: Changing meanings and perceptions within a 'marginal' Alpine landscape-the integration of palaeoecological and archaeological data in a high-altitude landscape in the French Alps. World Archaeology 38: 436-454.

Ward JH (1963) Hierarchical grouping to optimize an objective function. Journal of the American Statistical Association 58: $236-244$.

Wegmüller S (1977) Pollenanalytische Untersuchungen zur spätund postglazialen Vegetationsgeschichte der französichen Alpen (Dauphiné). Bern: Verlag Paul Haupt.

Woodbridge J, Roberts N and Fyfe R (2018) Pan-Mediterranean Holocene vegetation and land-cover dynamics from synthesised pollen data. Journal of Biogeography. 